\title{
A study into different cell-level cooling strategies for cylindrical lithium-ion cells in automotive applications
}

\author{
Daniel Worwood* \\ Warwick Manufacturing Group, \\ University of Warwick Coventry, \\ CV4 7AL, UK \\ Email: d.worwood@warwick.ac.uk \\ *Corresponding author
}

\author{
R. Algoo \\ Jaguar Land Rover, \\ International Digital Laboratory Coventry, \\ CV4 7AL, UK \\ Email: ralgoo@jaguarlandrover.com
}

\section{Ryan J. McGlen}

Thermacore Europe,

Unit 12/Wansbeck Business Park,

NE63 8QW, Ashington, UK

Email: ryan.mcglen@aavid.com

\section{James Marco and David Greenwood}

Warwick Manufacturing Group,

University of Warwick,

Coventry, CV4 7AL, UK

Email: James.Marco@warwick.ac.uk

Email: D.Greenwood@warwick.ac.uk

\begin{abstract}
Previous research has identified that the ageing rate and performance of lithium-ion cells is negatively influenced by unfavourable cell thermal conditions, specifically, high ambient temperatures and large in-cell temperature gradients. In this paper, the thermal performance of tab cooling cylindrical cells, which is not well understood within the literature, is compared to more common radial cooling strategies. The analysis is conducted through the development of a 2D transient bulk layer thermal model displaying anisotropic thermal conductivity. The model is validated against experimental temperature measurements, where the peak error of the simulation was found to be $2 \%$ and $5 \%$ for the experimental test drive cycle and constant $1 \mathrm{C}$ discharge respectively. Results indicate that radial cooling with air or singular tab cooling with liquid is inadequate in limiting in-cell temperature gradients to below $5^{\circ} \mathrm{C}$ for HEV type 32113 cells when subject to four loops of the US06 drive cycle.
\end{abstract}


Keywords: anisotropic thermal conductivity; automotive battery; thermal management; thermal modelling; tab cooling.

Reference to this paper should be made as follows: Worwood, D., Algoo, R., McGlen, R.J., Marco, J. and Greenwood, D. (2018) 'A study into different cell-level cooling strategies for cylindrical lithium-ion cells in automotive applications', Int. J. Powertrains, Vol. 7, Nos. 1/2/3, pp.199-226.

Biographical notes: Daniel Worwood obtained his MEng in Chemical Engineering from the Imperial College London prior to undertaking his Engineering Doctorate at the University of Warwick. His research focuses on the development of next generation thermal management techniques (employing advanced solid conduction) for lithium-ion battery cells.

R. Algoo has previously worked in the Formula One industry whereby his expertise lies with computational fluid dynamics modelling of automotive aerodynamics. Recently, his research interests have involved the characterisation and thermal analysis of both pouch type and cylindrical format lithium-ion battery cells which he has conducted whilst at Jaguar Land Rover UK.

Ryan J. McGlen is an Advanced Technology Manager at the Thermacore Europe Ltd., where he leads the Advanced Technology Group, who conducts research into next generation thermal technologies. He has over 15 years of experience in the design of electronics cooling systems and is Principal Engineer on two European space agency funded projects. He leads the industrial contribution on lithium-ion battery thermal management, in collaboration with the Warwick Manufacturing Group, based at the University of Warwick.

James Marco is a Chartered Engineer and reader in Vehicle Electrification and Energy Storage at the WMG, University of Warwick, with 20 years of experience leading collaborative research teams across industry and academia. His research interests include: powertrain energy management, energy storage modelling, battery system control and design optimisation.

David Greenwood leads the Advanced Propulsion Systems Team at the WMG which covers a wide remit of related areas within energy storage (battery systems); energy conversion (electric machines; power electronics); and energy management. He leads the WMG's activities as the Advanced Propulsion Centre's Electrical Energy Storage Spoke and also provides academic leadership for the development of R\&D activities within the National Automotive Innovation Centre.

This paper is a revised and expanded version of a paper entitled 'A study into different cell-level cooling strategies for cylindrical lithium-ion cells in automotive applications' presented at Powertrain Modelling and Control conference (PMC2016), Loughborough, UK, 7th-9th September 2016. 


\section{Introduction}

The worthiness of lithium-ion batteries in the automotive sector is a result of their superior energy and power density relative to previous iterations of battery technology such as lead acid and nickel-metal hydride (Yoo et al., 2014). Recent dramatic declines in the cost of lithium-ion batteries (Nykvist and Nilsson, 2015) are also fuelling the uptake of hybrid electric vehicles (HEVs), plug-in hybrid electric vehicles (PHEVs) and full electric vehicles (EV) into the automotive landscape, with forecasts predicting increased penetration rates of these vehicles within the commercial light duty vehicle market over the next 10 years (IEA, 2011).

Other important automotive battery metrics aside from cost include: life span - the time the battery can satisfy the operating requirements of the vehicle, safety - which is generally associated with thermal runaway avoidance and performance - the ability of the battery to meet the vehicle operational requirements under extremes in the ambient temperature, e.g., below $-20^{\circ} \mathrm{C}$ and above $40^{\circ} \mathrm{C}$ (Dinger et al., 2010). Unfortunately these are areas where lithium-ion batteries show weaknesses, as their performance (Tourani et al., 2014) and ageing rate is highly sensitive to the operating temperature (Bandhauer et al., 2011). As such, in order to ensure that the battery power and energy density is not compromised, which could hamper the uptake of HEVs and EVs, the adverse temperature related effects must be mitigated through ensuring that the volume average cell operating temperature is maintained within a range of circa $20 \pm 5^{\circ} \mathrm{C}$ (Tourani et al., 2014).

Aside from the average value of battery operating temperature, temperature gradients present between battery cells within a pack and also between the individual cell material layers have been shown to negatively impact performance and ageing (Troxler et al., 2014; Fleckenstein et al., 2011; Yang et al., 2016). Reports in literature suggest that temperature gradients between lithium-ion cells in a pack and through the individual cells should not exceed a maximum of $5^{\circ} \mathrm{C}$ (Yang et al., 2016). Hunt et al. (2016) further highlighted that not only does the magnitude of the formed temperature gradient affect cell performance and ageing, but also the direction of the gradient. They observed that the ageing rate for surface cooling of pouch cells was accelerated by a factor of 3 relative to that when tab cooling under a similar volume average cell temperature. This was due to the heightened ageing rate associated with perpendicular temperature gradients across the layers of the cell induced by surface cooling methods.

Tab cooling methods produce a more favourable axial temperature gradient along all the individual cell layers, but this strategy may suffer from increased cell operating temperatures due to smaller accessible surface area at the tabs, potentially offsetting the benefit of an improved gradient. Primary factors that influence the nature of the temperature gradients within battery cells are the strategy of cooling applied at the cell surfaces together with the aggressiveness of the electrical loading condition. Shah et al. (2014b) conducted steady-state thermal modelling on 26650 format cylindrical batteries when subject to an intense uniform heat generation rate of $6 \mathrm{~W}$. They observed that due to the severe thermal anisotropy present with the cell material, radial cooling at the outer 
surface lead to the formation of large perpendicular temperature gradients $\left(>20^{\circ} \mathrm{C}\right)$. They concluded that increasing the degree of convection at the tabs of the cell had the potential to reduce the magnitude of the thermal gradient through utilising the more efficient axial heat conduction pathways present within the cell. They did not, however, examine the potential for sole tab cooling as a thermal management solution without the radial cooling component, which produced the unfavourable predominate perpendicular gradient.

Common approaches to the thermal management of cylindrical cells to date have focused on cooling the outer radial surface, either via the use of external liquid channels (Zhao et al., 2015) or through direct forced convection cooling with air or dielectric liquid (Park and Jung, 2013). However, as of yet, there is a clear deficiency in available literature that specifically focuses on identifying the electrical loading limits under which radial cooling and, in particular, tab cooling strategies fail to meet the aforementioned thermal constraints of the cell. The choice of an exclusive tab cooled strategy over a radial cooled strategy is thus not well defined in regard to its thermal performance within electrified automotive applications. This paper addresses this issue by analysing the cooling performance of both radial and tab cooling methods for cylindrical cells when subject to a wide range of electrical loading conditions that reflect aggressive yet realistic use scenarios for a representative EV, PHEV and HEV. This facilitates the decision into the potential preferred thermal management strategy for a given application that minimises the detrimental thermal related effects on the cell.

The paper is structured as follows. Section 2 outlines the development of the thermal model with Section 3 validating its accuracy against experimental temperature measurements from real 18650 cells subject to two different current profiles. Section 4 contains the cooling case study analysis, which includes a discussion on the vehicle model used to obtain the electrical duty cycles together with the results of the thermal modelling. A sensitivity analysis on the effect of the cell anisotropic thermal conductivity parameters on the outputted cell thermal response is included in Section 5. Recommendations for further work and conclusion are discussed in Sections 6 and 7 respectively.

\section{Thermal model}

A bulk layer assumption as outlined in Drake et al. (2014) and Shah et al. (2014a, 2014b) is used to model the cell. Within the bulk layer, an effective heat capacity and density is chosen to represent the complete cell structure. To ensure that dominate thermal pathways within the cell are correctly accounted for, thermal anisotropy within the cell material is also included. With such a model, values for the thermal conductivity parameters represent effective values for the complete cell structure. As such, methods to determine their value used as an input into the thermal model should be based off experimental measurements performed on a complete cell structure to ensure that the presence of thermal contact resistances within the cell structure are implicitly included. An example of such experimental measurement techniques to determine the effective cell anisotropic thermal conductivity can be viewed in Drake et al. (2014). This avoids issues of underestimating the cell hot spot temperature and in-cell temperature gradient (Ye et al., 2014) associated with using theoretical calculations to determine the effective 
perpendicular thermal conductivity parameter based on the layer properties of the cell, as outlined in Chen et al. (2005) that neglect thermal contact resistances.

A schematic showing the bulk layer model for the cell material is viewable in Figure 1. The governing heat conduction equation for the cell bulk material is given by:

$$
\rho C_{p} \frac{\partial T}{\partial t}=q^{\prime \prime \prime} \mid+\frac{1}{r} \frac{\partial}{\partial r}\left(k_{r} r \frac{\partial T}{\partial r}\right)+\frac{\partial}{\partial z}\left(k_{z} \frac{\partial T}{\partial z}\right)
$$

ehere $\rho$ is the cell density $\left[\mathrm{kg} \cdot \mathrm{m}^{-3}\right], T$ the local cell temperature $[\mathrm{K}], C_{p}$ the cell heat capacity $\left[\mathrm{J}_{\mathrm{kg}}-1 \cdot \mathrm{K}^{-1}\right], r$ and $z$ the radial and axial positions respectively $[\mathrm{m}], R_{i}$ the radius of the cell mandrel [m], $R_{0}$ the radius of the cell [m], $z=0$ the location at the bottom tab of the cell $[\mathrm{m}], z=L$ the location at the top cell tab $[\mathrm{m}], q^{\prime \prime \prime}$ the uniform volumetric heat generation rate present within the cell [W. $\left.\mathrm{m}^{-3}\right], k_{r}$ the effective cell perpendicular thermal conductivity along the $r$ axis $\left[\mathrm{W} . \mathrm{m}^{-1} \cdot \mathrm{K}^{-1}\right]$ and $k_{z}$ the effective cell axial thermal conductivity along the $\mathrm{z}$ axis $\left[\mathrm{W} \cdot \mathrm{m}^{-1} \cdot \mathrm{K}^{-1}\right]$. Irreversible heat generation mechanisms are considered to characterise the value of $q^{\prime \prime \prime}$, whereby other heat generation terms such as entropic heating are ignored. The irreversible volumetric heat generation rate is expressed via (Onda et al., 2006):

$$
q^{\prime \prime \prime}=\frac{I^{2} R_{\eta}}{v_{c}}
$$

where $I$ is the cell current [A], $R_{\eta}$ the overpotential resistance of the cell [ $\Omega$ ] and $v_{c}$ the volume of the cell active material $\left[\mathrm{m}^{3}\right]$.

Figure 1 Schematic of cell geometry represented as a homogenous bulk layer with anisotropic thermal conductivity

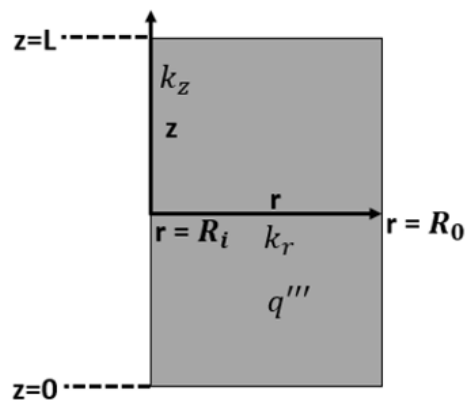

One common method that has proven accurate for solving the heat conduction equation in $2 \mathrm{D}$ coordinates is the alternating-direction implicit (ADI) finite difference method (Ozisik, 1994), which has been adopted to solve equation (1). This technique discretises the heat conduction equation producing two ADI equations which are each solved in turn, given boundary conditions, using tri-diagonal matrices to determine the temperature values at the nodes. Details for the solution of the ADI equations for such a cylindrical coordinate system can be found in Schneider (2003). Newton's law of cooling is specified at the external cell surfaces. An insulating boundary condition is set at $r=R_{i}$ given the symmetry present within the cell. 


\section{Thermal model experimental validation}

The accuracy of the thermal model is assessed against experimental temperature measurements obtained from unaged 18650 energy cells with a nominal capacity rating of 3.1 Ah subject to two test duty cycles. The cells are placed in a climate chamber that circulates air at $25^{\circ} \mathrm{C}$. Thermocouples are placed at the top, bottom and mid-height exterior surface of the cells facing outward from the module. Figure 2 shows the experimental setup and an example of the location of the thermocouples as indicated by the stars. Only temperature monitored cells are shown (labelled 1-5). The 19 cells within the module are connected in parallel during testing.

Figure 2 Experimental setup showing temperature monitored cells within a 19 cell module (see online version for colours)

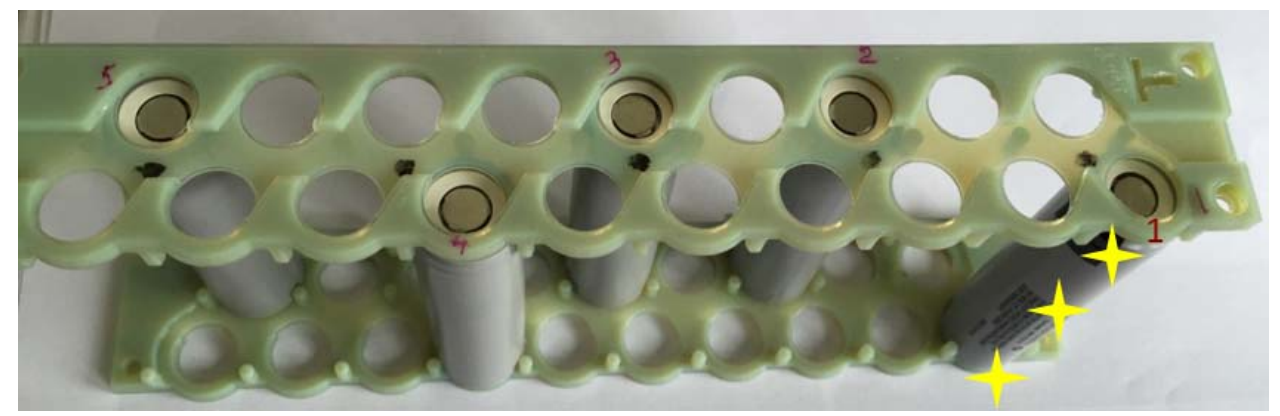

The physical thermal parameters for the cell as model inputs are viewable in Table 3.

The value for the effective cell density is calculated given the weight of the cell $(40 \mathrm{~g})$ and the known volume of the cell active material [a $3 \mathrm{~mm}$ cell mandrel size is assumed based on images from Brand et al. (2015)].

The value for the cell effective heat capacity is given by the cell manufacturer. Values to define the cell effective perpendicular thermal conductivity are chosen based off literature values that implicitly include the contribution of thermal contact resistance present between layers in the electrode assembly. These typically give rise to values in the region of $0.15-0.28 \mathrm{~W} \cdot \mathrm{m}^{-1} \cdot \mathrm{K}^{-1}$, near a magnitude lower than measured values for isolated electrode assembly samples (Maleki, 1999). The axial thermal conductivity value is taken from Drake et al. (2014) which is determined from experimental measurements and similar to values reported elsewhere for the effective axial thermal conductivity of lithium-ion batteries (Bazinski et al., 2016). The $R_{\eta}$ value of the cell is measured experimentally as a function of the cell state of charge (SOC) using the pulse method technique described in Schweiger et al. (2010) with a $10 \mathrm{~s}$ pulse duration performed at $25^{\circ} \mathrm{C}$. The results are viewable in Figure 3(a) together with the test drive cycle cell C-rate profile in Figure 3(b).

Comparison results between the thermal model outputs and the experimental cell mid-height surface temperature measurements from cell 1 (as seen in Figure 2) for both test cases are shown in Figure 4. The convective coefficient value employed at the radial and bottom tab surface is $6 \mathrm{~W} \cdot \mathrm{m}^{-1} \cdot \mathrm{K}^{-1}$ [within the region of natural convection with air across a cylinder (Bergman et al., 2011)]. The suggested higher value of $10 \mathrm{~W} \cdot \mathrm{m}^{-2} \cdot \mathrm{K}^{-1}$ from Shah et al. (2014a) is set at the top tab which is more exposed to the air circulation effect from the climate chamber. Mesh resolution parameters for space and time in the 
finite difference model are chosen to ensure that the model output is independent of their value.

Figure 3 (a) Experimental cell overpotential resistance (b) Test drive cycle c-rate profile (see online version for colours)

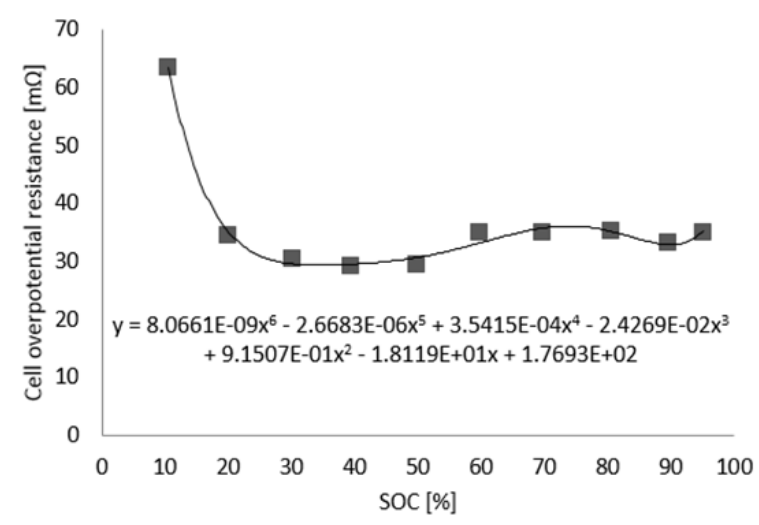

(a)

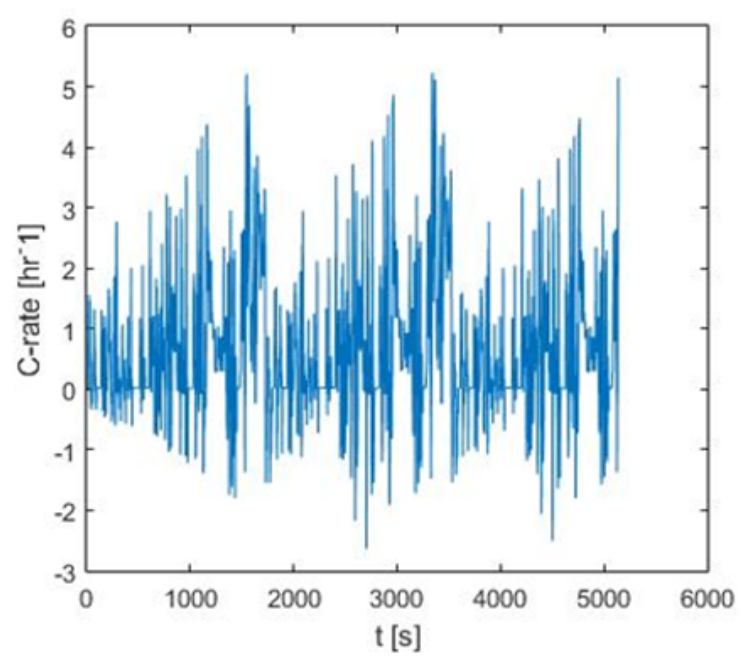

(b)

The model provides good agreement with the experimental measurement for both cases with a peak error of $5.3 \%$ for the $1 \mathrm{C}$ discharge and $2.4 \%$ for the test drive cycle duty cycles. The use of the $R_{\eta}$ polynomial is used for the $1 \mathrm{C}$ discharge, given that the deep SOC discharge results in a large increase in $R_{\eta}$. The model slightly under predicts the temperature within the low SOC range $<17 \%$ where the large increase in $R_{\eta}$ begins. This discrepancy may be a result of neglecting the entropic heating effect, which can be greater than $10 \%$ the value of the irreversible heat term between $0 \%-20 \%$ SOC depending on chemistry type at $1 \mathrm{C}$ discharge (Viswanathan et al., 2010). For the test drive cycle, the cell SOC does not drop below $17 \%$ and therefore avoids the region of large resistance increase and potential higher contributions from entropy heating. To 
bypass Coulomb-counting given that $R_{\eta}$ varies little between $100-17 \%$ SOC, a nominal value of $32 \mathrm{~m} \Omega$ is used in the thermal model for the test drive cycle case. Through avoiding the lower SOC region, the error arising from extrapolation of the polynomial curve to calculate $R_{\eta}$ at SOC levels below $10 \%$ is avoided, which may explain why the overall observed experimental error is less for the test drive cycle case.

Figure 4 Mid-height outer cell surface temperature (a) constant $1 \mathrm{C}$ discharge (b) test drive cycle (see online version for colours)

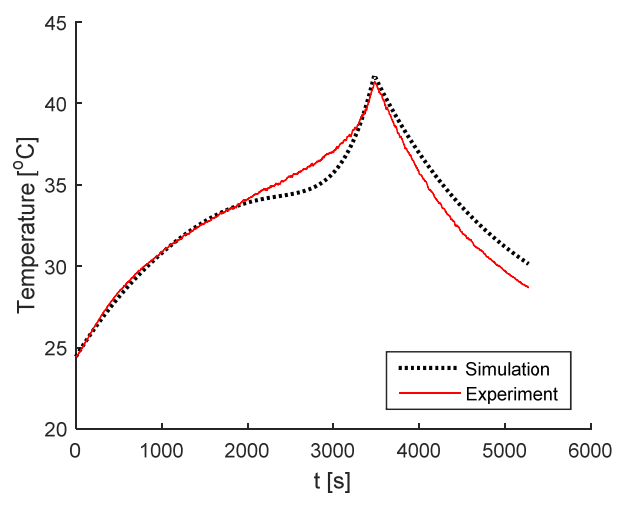

(a)

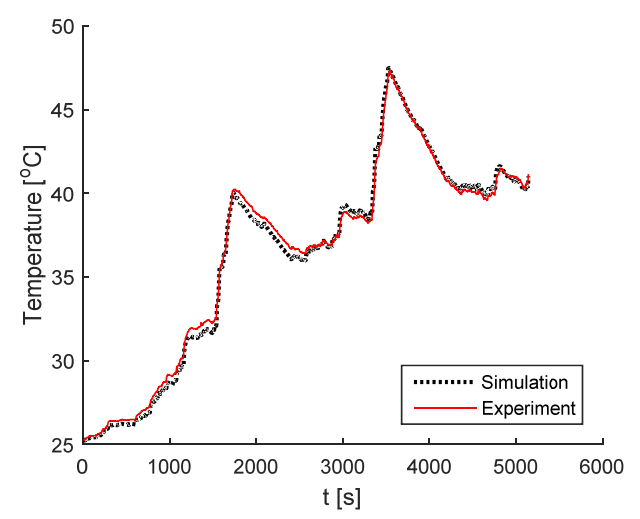

(b)

\section{Cooling case study analysis}

In this section, the effectiveness of conventional cylindrical cell-level cooling strategies are analysed when subject to their representative electrical loading condition and cell format. Five possibilities of exterior cell cooling exist for cylindrical cells which are:

a radial surface cooling

b single tab cooling

c single tab cooling + radial cooling

d both tab cooling

e both tab and radial cooling (all sides).

A schematic representation of each of these cooling approaches is shown in Figure 5. Here, the insulated boundaries where no heat transfer occurs is represented by the dashed rectangles, with the cell material by the homogenous grey larger rectangles. Where there is no insulation, convective cooling exists which is represented by the presence of a convective heat transfer coefficient $\left[h_{z 0}, h_{z l}\right.$ and $h_{r}$ for the bottom tab, top tab and outer radial surface respectively $\left.\left(\mathrm{W} \cdot \mathrm{m}^{-2} \cdot \mathrm{K}^{-1}\right)\right]$. It is noted that schematic (b) and (c) in Figure 5 may also be expressed as top tab and top tab and radial cooling respectively, in which bottom tab cooling is shown in this instance.

The first two cases (a) and (b) represent typical cooling choices, with a form of radial cooling being employed in the current model of the Tesla Model S (Anderman, 2014). The last three represent a more involved cooling approach which targets cooling at 
multiple exterior surfaces of the cell. Such approaches would require a more complicated cooling design, achieved either through direct submersion of the cell within a dielectric heat transfer medium [potential for case (e)] or through a cooling jacket/discrete tubing that encompasses more than one surface for the cell. All approaches utilise only exterior cell cooling and do not cool at the cell core which is representative of the current general approach for battery thermal management (Wang et al., 2016).

The intensity of the cooling applied at the associated boundary surface(s) represents the choice of the heat transfer medium, as the convection coefficient is a function of its thermal properties (Bergman et al., 2011). For the heat transfer medium choice, air and liquid (water-glycol) are considered. A value $50 \mathrm{~W} \cdot \mathrm{m}^{-2} \cdot \mathrm{K}^{-1}$ [similar to that reported in Kim and Pesaran (2006)] is chosen to reflect forced convection of air in parallel flow across the outer surface of a cylindrical battery cell. A value of $750 \mathrm{~W} \cdot \mathrm{m}^{-2} \cdot \mathrm{K}^{-1}$ is chosen to represent the convective coefficient obtainable with water-glycol (Kim and Pesaran, 2006). In all instances the temperature of the bulk heat transfer medium is set as a constant at $25^{\circ} \mathrm{C}$.

Figure 5 Schematic of different approaches for externally cooling cylindrical battery cells (a) radial cooling (b) bottom tab cooling (c) bottom tab and radial cooling (d) both tab cooling (e) both tab and radial cooling/all sides cooling

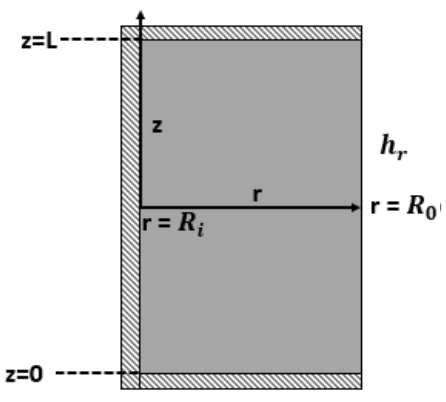

(a)

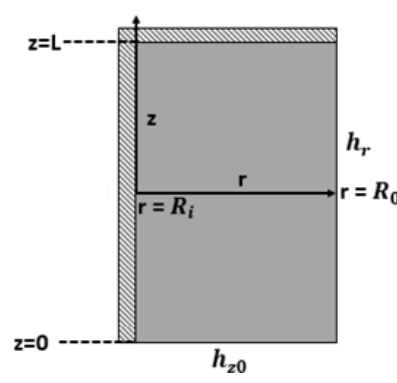

(c)

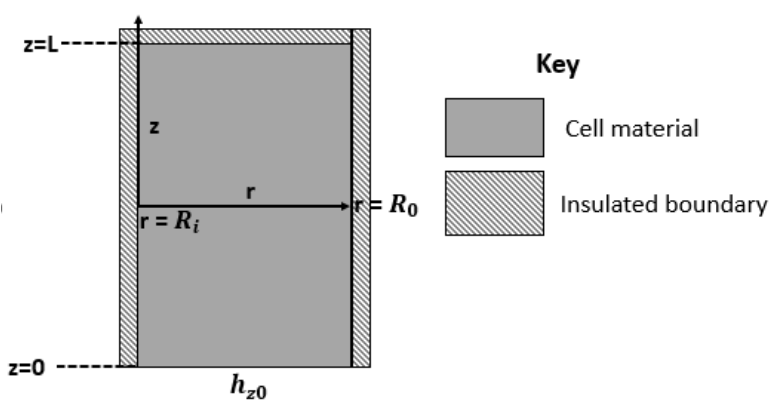

(b)

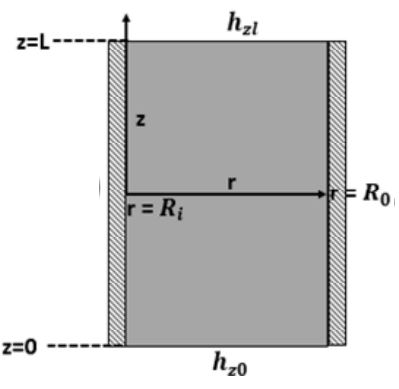

(d)

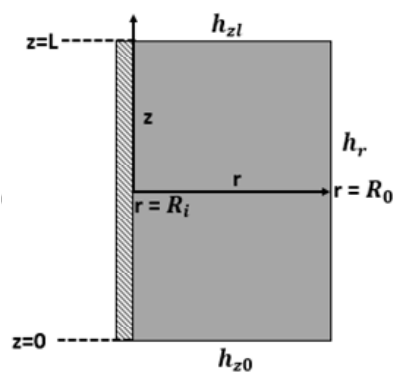

(e)

\subsection{Cell electrical loading conditions for case study analysis}

The electrical current profiles for the EV and PHEV vehicle cases are derived from a 1D, backward-facing, lumped parameter vehicle model similar to that described in Peterson et al. (2010). For the PHEV case, the electrical loading condition on the battery is representative of a PHEV operating in electric only mode. The input to the EV vehicle 
model is the velocity profile of the US06, whereby the PHEV model considers both the WLTP Class 3 (Tutuianu et al., 2014) and Artemis Rural Road drive cycle (Barlow et al., 2009). The US06 is not considered for the PHEV case due to the peak C-rate of the cell exceeding 5.5C, which is outside the permissible tolerance of the cell. Propulsion power $(\mathrm{Pp})$ on the battery is derived using the standard road law equation, comprising rolling resistance and aerodynamic drag forces. The effective power at the terminals of the battery pack is reflected through the efficiency of the powertrain components (e.g., electrical machine, gearing and power electronics). During periods of regenerative braking, $24 \%$ of $\mathrm{Pp}$ is applied to the battery pack, with the balance dissipated as heat in the friction brakes and electric motor and inverter losses. Table 1 presents the key vehicle and battery parameters considered in the model. For the HEV case, the US06 power profile as presented in Johnson et al. (2000) is employed with the limit upscaled to match $40 \mathrm{~kW}$, typical for the maximum power of a HEV electrical machine (Rabenstein et al., 2011).

Figure 6 Cell C-rate profiles for the simulation case study analysis (a) EV US06 (b) HEV US06 (c) PHEV WLTP Class 3 (d) PHEV Artemis rural road (see online version for colours)

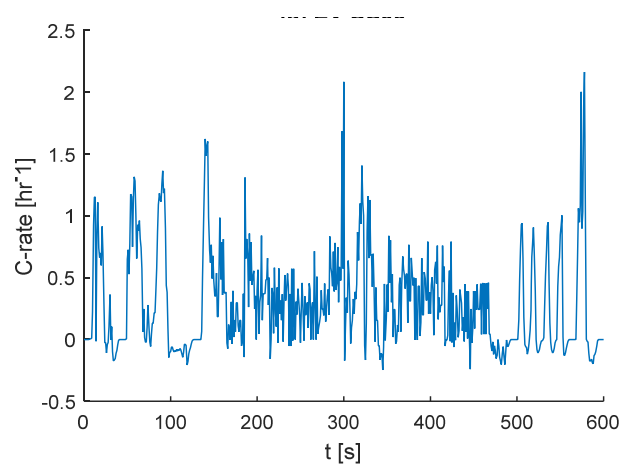

(a)

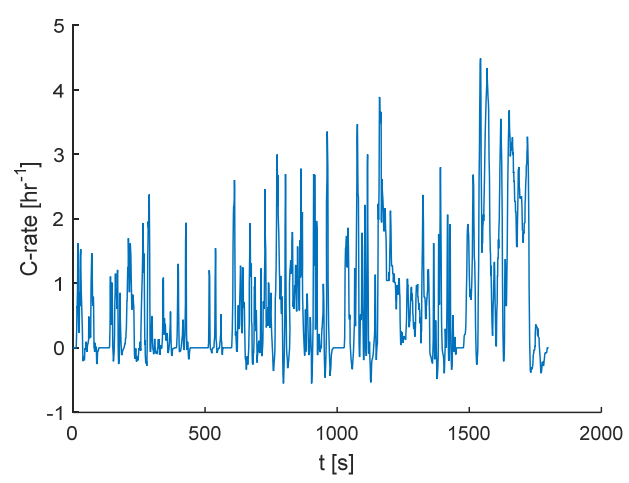

(c)

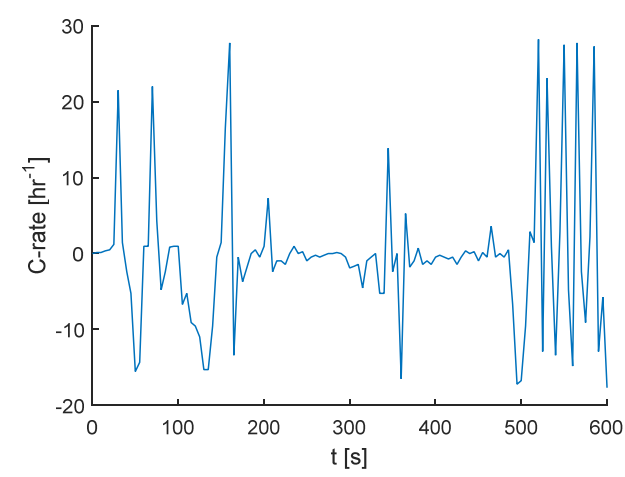

(b)

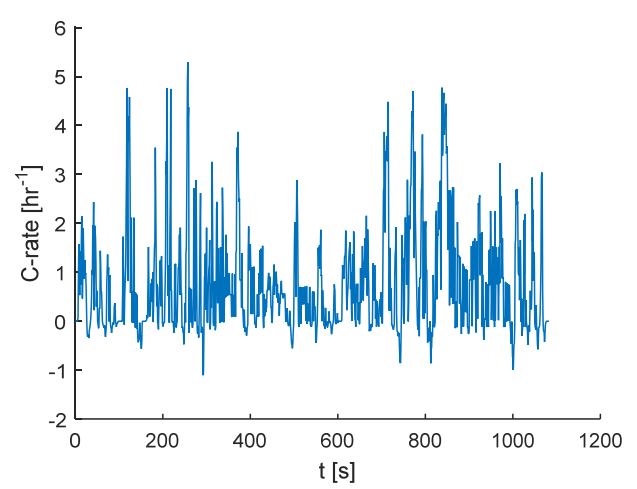

(d)

In Table $1, C_{d}$ is the drag coefficient, $V_{\text {cell }}$ the cell voltage [V], $N_{\text {cell }}$ the number of cells in the battery pack, $C_{\text {cell }}$ the nominal cell capacity $[\mathrm{Ah}]$ and $E_{\text {pack }}$ the nominal pack energy $[\mathrm{kWh}]$. Cell formats considered for each category are as follows. Common high energy 18650 cells rated at $3.1 \mathrm{Ah}$ as utilised in the experimental validation section are 
employed in EV and PHEV vehicle models. For the HEV case, larger 32113 cells are chosen to reflect those commonly employed in HEV applications (A123 Systems, 2011). The mass of the 32113 cell based on the A123 data sheet is $205 \mathrm{~g}$ (A123 Systems, 2011).

Table 1 Example EV, PHEV vehicle and battery parameters and HEV battery parameters

\begin{tabular}{lcccccccc}
\hline & $\begin{array}{c}\text { Curb weight }+ \\
80 \mathrm{~kg} \text { driver }[\mathrm{kg}]\end{array}$ & $\begin{array}{c}\text { Frontal } \\
\text { area }\left[\mathrm{m}^{2}\right]\end{array}$ & $\begin{array}{c}C_{d} \\
{[-]}\end{array}$ & $\begin{array}{c}\text { Cell } \\
\text { type [-] }\end{array}$ & $\begin{array}{c}V_{\text {cell }} \\
{[\mathrm{V}]}\end{array}$ & $\begin{array}{c}N_{\text {cell }} \\
{[-]}\end{array}$ & $\begin{array}{c}C_{\text {cell }} \\
{[\mathrm{Ah}]}\end{array}$ & $\begin{array}{c}E_{\text {pack }} \\
{[\mathrm{kWh}]}\end{array}$ \\
\hline $\begin{array}{l}\text { Example } \\
\text { EV }\end{array}$ & 2,188 & 2.33 & 0.24 & 18650 & 3.7 & 7104 & 3.1 & 81 \\
$\begin{array}{l}\text { Example } \\
\text { PHEV }\end{array}$ & 1,801 & 2.20 & 0.28 & 18650 & 3.7 & 1395 & 3.1 & 16 \\
$\begin{array}{l}\text { Example } \\
\text { HEV }\end{array}$ & {$[-]$} & {$[-]$} & {$[-]$} & 32113 & 3.3 & 96 & 4.5 & 1.4 \\
\hline
\end{tabular}

The determined C-rate profiles using the outputted current profiles from the vehicle model together with the nominal cell capacity are displayed in Figure 6.

Table 2 Time averaged heat generation rate values for each electrical loading condition considered

\begin{tabular}{lc}
\hline Case study scenario & Time averaged cell heat generation rate $[W]$ \\
\hline EV (81 kWh) US06 (18650 cell) & 0.078 \\
EV (81 kWh) 1C fast charge (18650 cell) & 0.308 \\
HEV (1.4 kWh) US06 (32113 cell) & 6.307 \\
PHEV (16 kWh) WLTP Class 3 (18650 cell) & 0.398 \\
PHEV (16 kWh) Artemis rural road (18650 cell) & 0.529 \\
\hline
\end{tabular}

The calculated heat generation profile obtained from the current profile and use of equation (2) are shown in Figure 7. Both the full transient profile and the time averaged value for the heat generation rate across the profile is shown. Values for the time averaged profiles are summarised in Table 2.

Table 3 Physical properties of battery cells used in simulation

\begin{tabular}{|c|c|c|c|c|c|c|c|c|}
\hline $\begin{array}{l}\text { Cell } \\
\text { format }\end{array}$ & $\begin{array}{c}k_{z} \\
{\left[W \cdot m^{-1} \cdot K^{-1}\right]}\end{array}$ & $\begin{array}{c}k_{r} \\
{\left[W \cdot m^{-1} \cdot K^{-1}\right]}\end{array}$ & $\begin{array}{c}C_{p} \\
{\left[J \cdot \mathrm{kg}^{-1} \cdot K^{-1}\right]}\end{array}$ & $\begin{array}{c}\text { Cell } \\
\text { mass }[\mathrm{g}]\end{array}$ & $\rho\left[\mathrm{kg} \cdot \mathrm{m}^{-3}\right]$ & $\begin{array}{c}\text { Mandrel } \\
\text { size } \\
{[\mathrm{mm}]}\end{array}$ & $\begin{array}{c}\text { Nominal } \\
\text { cell } \\
\text { capacity } \\
{[\mathrm{Ah}]}\end{array}$ & $\begin{array}{l}\text { Nominal } \\
R_{\eta}[\mathrm{m} \Omega]\end{array}$ \\
\hline 18650 & $\begin{array}{l}30 \text { (Drake } \\
\text { et al., 2014) }\end{array}$ & $\begin{array}{c}0.25 \text { (Shah } \\
\text { et al., 2016) }\end{array}$ & 1,015 & 40 & 2,418 & $\begin{array}{c}3 \\
\text { (Brand } \\
\text { et al., } \\
2015 \text { ) }\end{array}$ & 3.1 & 32 \\
\hline 32113 & 30 & 0.25 & $\begin{array}{c}1,020 \\
\text { (Fleckenstein, } \\
\text { et al., 2013) }\end{array}$ & $\begin{array}{c}205 \\
\text { (A123 } \\
\text { Systems, } \\
011)\end{array}$ & 2,276 & 3 & 4.5 & 4 \\
\hline
\end{tabular}

A $1 \mathrm{C}$ fast charge condition is also included to reflect a potential more strenuous condition for the large sized EV. Across the $90 \%-20 \%$ SOC region, the constant heat generation rate for a $1 \mathrm{C}$ charge given the static value of $32 \mathrm{~m} \Omega$ for the internal resistance is 
$0.308 \mathrm{~W}$, which is circa four times larger than the time averaged heat generation rate across the EV US06 cycle.

The thermal properties of both cell format types used in the subsequent thermal modelling study are summarised in Table 3.

Figure 7 Cell heat generation rate profiles for the simulation case study analysis (a) EV US06 (b) HEV US06 (c) PHEV WLTP Class 3 (d) PHEV Artemis rural road (see online version for colours)

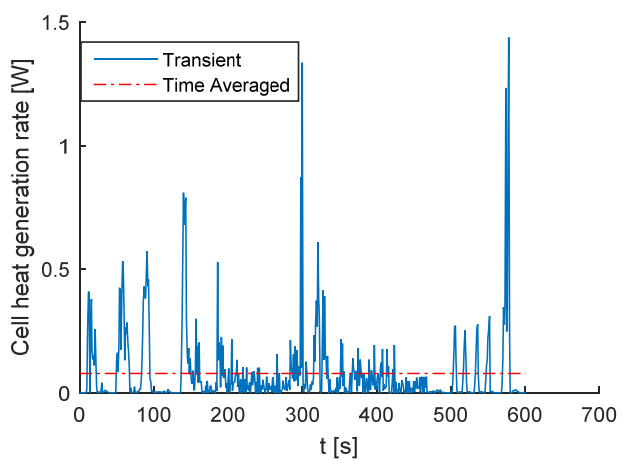

(a)

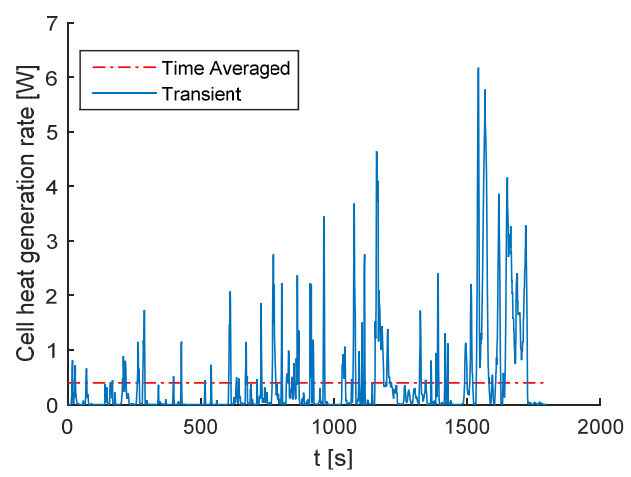

(c)

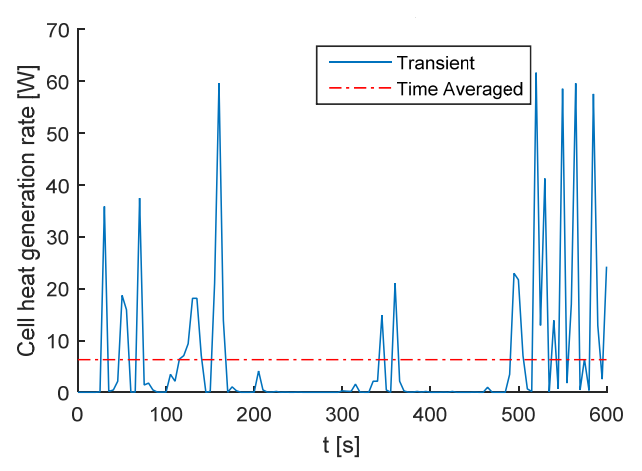

(b)

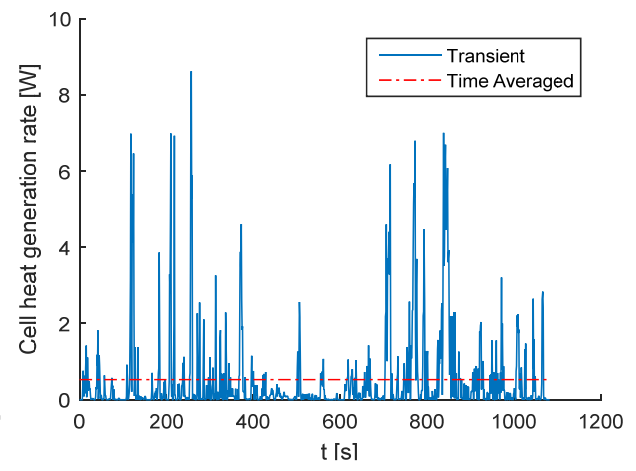

(d)

\subsection{Steady state thermal analysis}

A steady-state analysis is conducted to rank each cooling strategy in order of their thermal effectiveness. Steady-state results are useful as the constant cell heat generation rate can be set as the time average heat generation value across a given transient drive cycle, which provides an initial indication into the potential thermal performance of the cooling method prior to running the full transient model.

The relationship between the steady state values of maximum cell temperature $\left(T_{\max }\right)$, maximum cell temperature gradient $\left(\Delta T_{\max }\right)$ and internal heat generation rate as a function of the cooling strategy for the 18650 cell are displayed in Figure 8 . The most aggressive time averaged values of cell heat generation from Table 3 are displayed by the vertical arrows, which reflect potential realistic limits for the cell operation (in which to design the thermal management system against) for both the simulated EV and PHEV. 
The horizontal arrow represents the $5^{\circ} \mathrm{C}$ threshold for $\Delta T_{\max }$, which has been considered by many (Yang et al., 2016; Greco et al., 2014; Rao et al., 2013) to be a design constraint for the thermal management system to avoid excessive battery degradation rates.

Employing air as the heat transfer medium is suitable for both limiting heat generation cases in enabling $\Delta T_{\max }$ to remain below $5^{\circ} \mathrm{C}$. For $1 \mathrm{D}$ heat transfer strategies (radial and tab cooling) $\Delta T_{\max }$ remains unaltered upon increasing the convection rate to represent forced liquid cooling. During a transient electrical loading, increasing the degree of cooling at a given target surface will result in steady state occurring sooner, thus the rise in $\Delta T_{\max }$ upon initiation of the cooling will be greater for the liquid system relative to the air system. This consideration is important if the characteristic time averaged heat generation values for the given electrical loading condition result in steadystate $\Delta T_{\max }$ values exceeding $5^{\circ} \mathrm{C}$, as the threshold may be surpassed during the duration of the use scenario.

Figure 8 Relationship between key 18650 cell thermal conditions and internal heat generation rate as a function of cooling strategy with (a) air $\left(\Delta T_{\max }\right.$ at $\left.h=50 \mathrm{~W} \cdot \mathrm{m}^{-2} \cdot \mathrm{K}^{-1}\right)$ (b) liquid $\left(\Delta T_{\max }\right.$ at $\left.h=750 \mathrm{~W} \cdot \mathrm{m}^{-2} \cdot \mathrm{K}^{-1}\right)$ (c) air $\left(T_{\max }\right.$ at $\left.h=50 \mathrm{~W} \cdot \mathrm{m}^{-2} \cdot \mathrm{K}^{-1}\right)$ (d) liquid $\left(T_{\max }\right.$ at $h=750 \mathrm{~W} \cdot \mathrm{m}^{-2} \cdot \mathrm{K}^{-1}$ ) (see online version for colours)
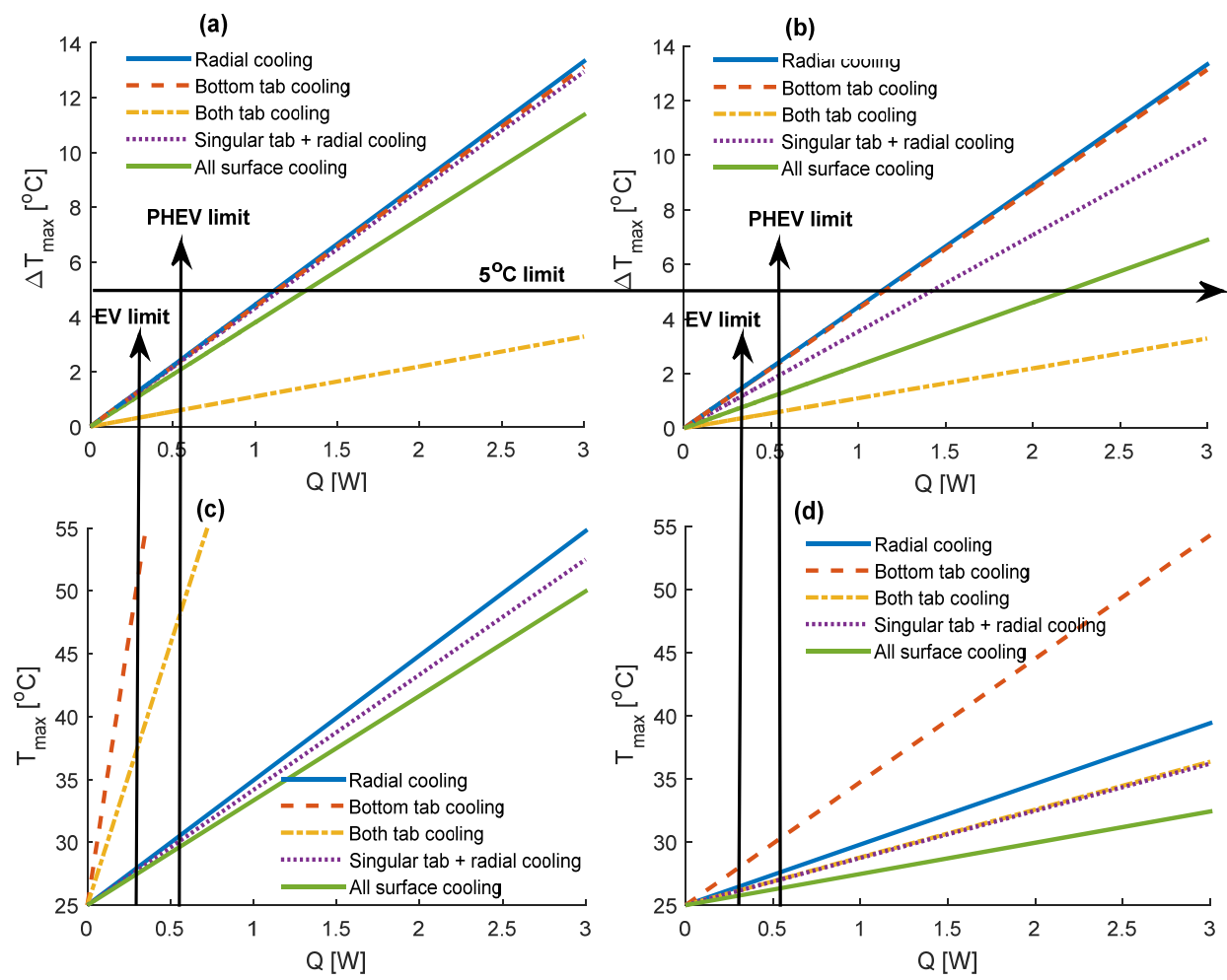

For 2D heat transfer strategies employing a combination of radial and tab cooling, $\Delta T_{\max }$ decreases upon increasing the convection rate from $50 \mathrm{~W} \cdot \mathrm{m}^{-2} \cdot \mathrm{K}^{-1}$ to $750 \mathrm{~W} \cdot \mathrm{m}^{-2} \cdot \mathrm{K}^{-1}$. This is a result of the improved degree of axial heat transfer from tab cooling relative to the diminishingly improved heat transfer rate in the perpendicular direction. 
Whilst tab cooling strategies with air may be suitable in providing acceptable values for $\Delta T_{\max }$, Figure 8(c) highlights that the much higher convective thermal resistance at the tabs owing to the reduced heat transfer area available results in the formation of high hot spot temperatures within the cell. For the EV limiting case, $T_{\max }$ approaches $50^{\circ} \mathrm{C}$ whereby for the PHEV case $T_{\max }$ greatly exceeds $55^{\circ} \mathrm{C}$. Radial cooling with air enables $T_{\max }$ to remain at circa $30^{\circ} \mathrm{C}$, which is acceptable given that this is only a $5^{\circ} \mathrm{C}$ rise in temperature relative to that of the bulk heat transfer medium. Upon increasing the convective coefficient to $750 \mathrm{~W} \cdot \mathrm{m}^{-2} \cdot \mathrm{K}^{-1}$, singular tab cooling provides a similar value for $T_{\max }$ as with air cooling for the radial case. Tab cooling methods are thus adequate choices of cell level thermal management for both the EV and PHEV cases if liquid cooling is employed.

Figure 9 Relationship between key 32113 cell thermal conditions and internal heat generation rate as a function of cooling strategy with (a) air $\left(\Delta T_{\max }\right.$ at $\left.h=50 \mathrm{~W} \cdot \mathrm{m}^{-2} \cdot \mathrm{K}^{-1}\right)$ (b) liquid $\left(\Delta T_{\max }\right.$ at $\left.h=750 \mathrm{~W} \cdot \mathrm{m}^{-2} \cdot \mathrm{K}^{-1}\right)(\mathrm{c})$ air $\left(T_{\max }\right.$ at $\left.h=50 \mathrm{~W} \cdot \mathrm{m}^{-2} \cdot \mathrm{K}^{-1}\right)(\mathrm{d})$ liquid $\left(T_{\max }\right.$ at $h=750 \mathrm{~W} \cdot \mathrm{m}^{-2} \cdot \mathrm{K}^{-1}$ ) (see online version for colours)
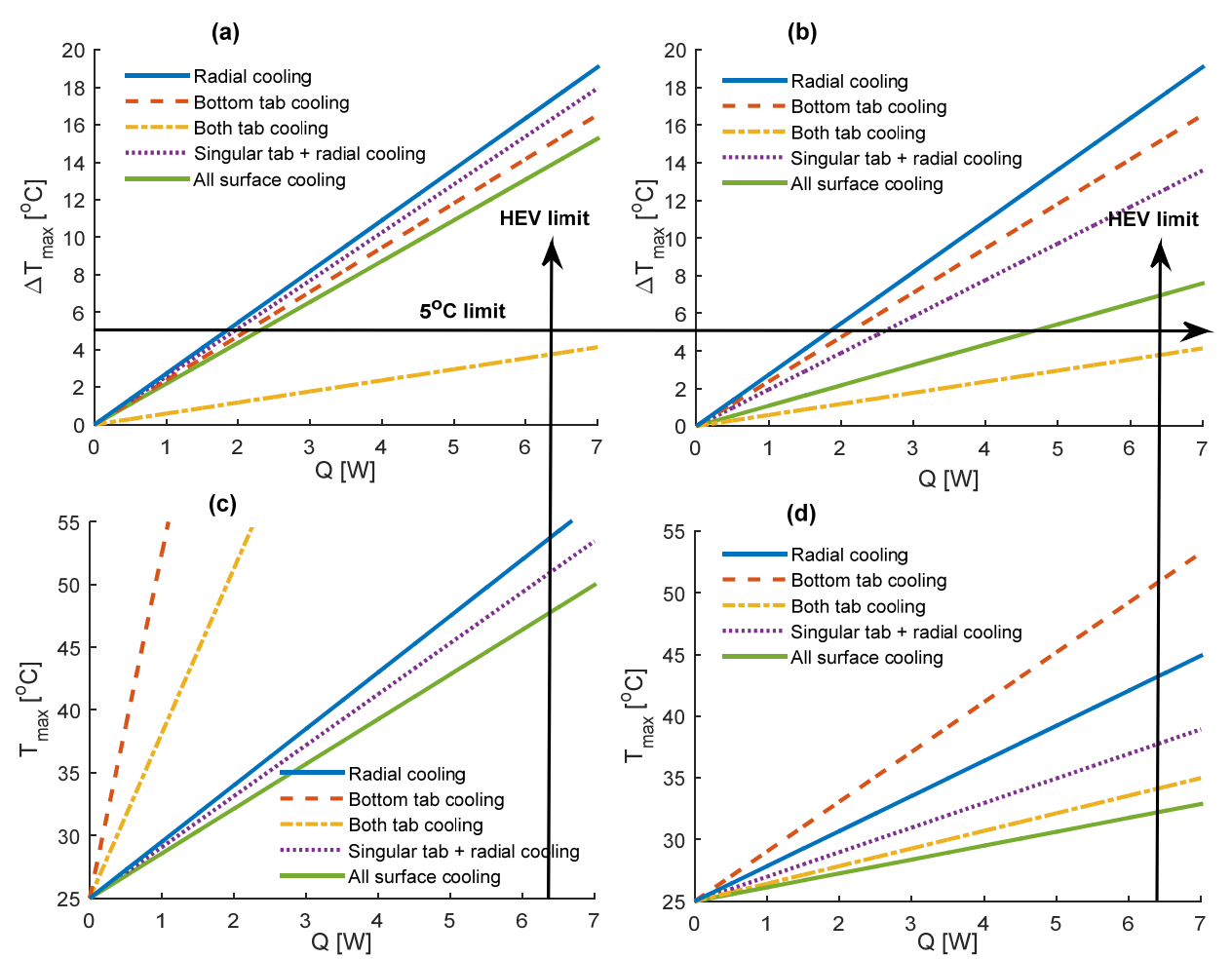

The benefits of cooling multiple surfaces of the cell with air are minimal within the PHEV heat generation limit region. Targeting additional surfaces of the cell will likely complicate the design of the duct system thus increasing the complexity of the complete pack-level design for minimal thermal gain. For these applications, therefore, air cooling should aim to solely target the complete radial surface. 
Figure 10 Steady-state temperature contours for 18650 type cell with $0.529 \mathrm{~W}$ heat generation for different external cooling strategies (a) radial cooling $\mathrm{h}=750 \mathrm{~W} \cdot \mathrm{m}^{-2} \cdot \mathrm{K}^{-1}$

(b) bottomtab cooling $\mathrm{h}=750 \mathrm{~W} \cdot \mathrm{m}^{-2} \cdot \mathrm{K}^{-1}$ (c) bottom tab + radial cooling $\mathrm{h}=750 \mathrm{~W} \cdot \mathrm{m}^{-2} \cdot \mathrm{K}^{-1}(\mathrm{~d})$ both tab cooling $\mathrm{h}=750 \mathrm{~W} \cdot \mathrm{m}^{-2} \cdot \mathrm{K}^{-1}$ (e) all surface cooling $\mathrm{h}=750 \mathrm{~W} \cdot \mathrm{m}^{-2} \cdot \mathrm{K}^{-1}$ (see online version for colours)

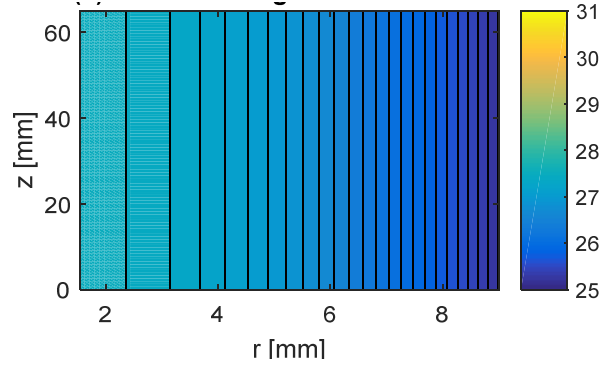

(a)

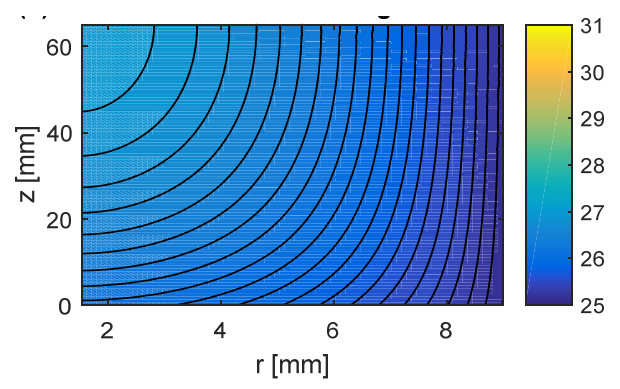

(c)

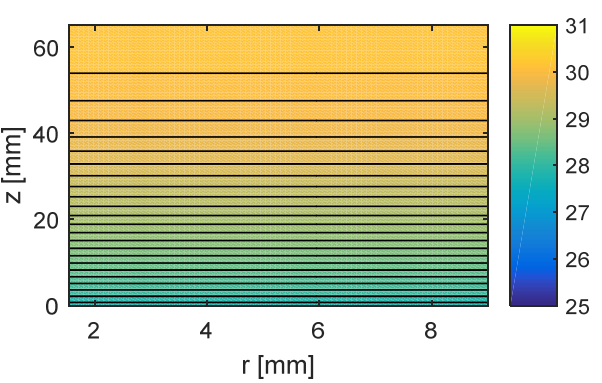

(b)

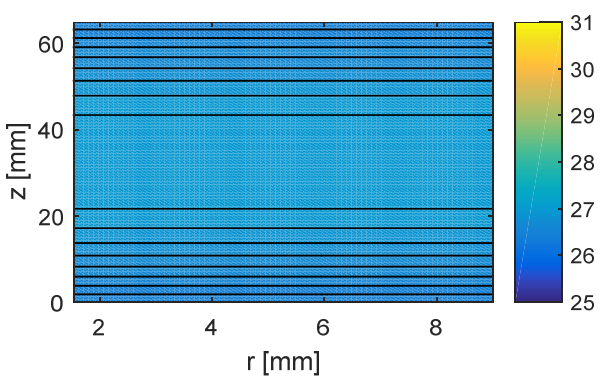

(d)

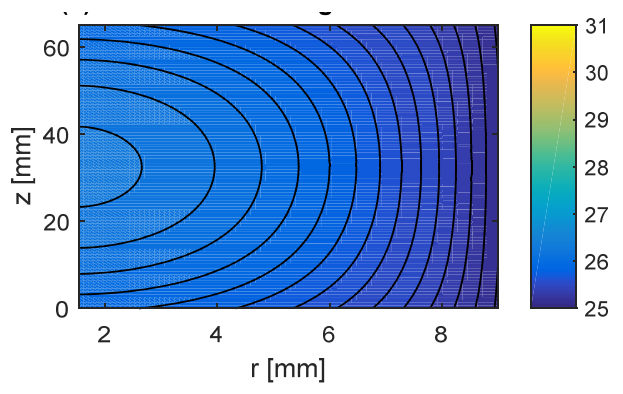

(e)

Note: All colour bar units in ${ }^{\circ} \mathrm{C}$.

The steady-state thermal results for the 32113 are displayed in Figure 9. The higher limit from the HEV time averaged heat generation rate renders cooling strategies that target only a singular surface of the cell ineffective for achieving a limit on $\Delta T_{\max }$ to $\leq 5^{\circ} \mathrm{C}$. Double tab cooling is the only strategy that enables $\Delta T_{\max }$ to remain below $5^{\circ} \mathrm{C}$ at the HEV limit. In addition, whilst cooling all surfaces of the cell results in the lowest hot spot temperature, the introduction of a radial cooling component actually worsens the 
temperature gradient relative to double tab cooling. The 2D heat transfer within the cell from combining tab cooling with radial cooling initiates the formation of complex multidirectional temperature gradients within the cell [as seen in Figures $10(\mathrm{c})$ and $10(\mathrm{e})]$. Given that the temperature gradients are not completely axial, it is expected that such a gradient will induce an increased ageing rate relative to if the same magnitude of gradient were completely axial (Hunt et al., 2016).

Compared to the 18650 cell, the increased aspect ratio of the 32113 cell (cell diameter divided by height) increases the effectiveness of tab cooling relative to radial cooling. Radial cooling with liquid can further reduce the hot spot temperature of the cell, however, the temperature gradient through the cell becomes increasingly problematic when subject to higher rates of heat generation. At the HEV limit, liquid radial cooling limits $T_{\max }$ to below $45^{\circ} \mathrm{C}$, however, $\Delta T_{\max }$ reaches $16^{\circ} \mathrm{C}$ leading to potentially severe conditions within the cell due to accelerated electrochemical related ageing effects (Fleckenstein et al., 2011).

Radial cooling with liquid may therefore be an inappropriate choice for all vehicle cases on the cell-level, as lower heat generation conditions where $\Delta T_{\max }$ remains below the $5^{\circ} \mathrm{C}$ threshold could be satisfied with air cooling, whereas high heat generation conditions become limited by the value of $\Delta T_{\max }$ which is governed by the thermal resistance within the cell and not the choice of heat transfer medium or exterior cooling intensity. Recommendations for the design of such systems as presented in Zhao et al. (2015) may therefore be misleading, particularly as their thermal modelling does not account for the thermal anisotropy present within the cell thus underestimating the magnitude of in-cell temperature gradients. Pack level considerations may, however, dictate the requirements of the heat transfer medium as other factors such as fan power and/or temperature rise of the bulk head transfer medium along the length of the cooling channel may become governing factors depending on the overall pack design strategy. Further discussion on the pack-level considerations for the thermal management strategy is out of the scope of this paper.

The thermal contours through the cell for the PHEV limit heat generation case and liquid cooled heat transfer medium are displayed in Figure 10. Cooling all surfaces of the cell with an equal $h$ value of $750 \mathrm{~W} \cdot \mathrm{m}^{-2} \cdot \mathrm{K}^{-1}$ at each surface results in the formation of a hot spot at the core of the cell. For sole radial cooling, the hot spot occurs along the axial length at the cell core. One advantage of bottom tab cooling is that the cell hot spot forms at the top tab, therefore temperature monitoring sensors can be placed at the more accessible top portion of the outer radial surface rather than at the core with radial cooling. This has the potential to improve the reliability of the battery management system as estimations of the core temperature are not required.

\subsection{Transient thermal analysis}

In this section, the full transient electrical loading profile is input into the thermal model to track the transient temperature evolution of both simulated cells subject to their respective electrical loading conditions. The transient analysis captures all of the thermal data, rather than using simplified heat generation averages and considers the duration of the cycle under its full usage duration. 


\subsubsection{Transient EV thermal analysis}

Thermal results for the EV vehicle model subject to four loops of the US06 cycle together with a 40 minute $1 \mathrm{C}$ charge (from $20 \%$ to $87 \%$ SOC) are shown in Figure 11. The volumetric average temperature evolution of the cell $\left(T_{\text {avg }}\right)$ is also shown.

Owing to the small time averaged cell heat generation rate across the US06 cycle of $0.0778 \mathrm{~W}$, as a result of the large pack size $(81 \mathrm{kWh})$, there is a small thermal effect on the cell. There is little fluctuation from the steady-state analysis using the time averaged heat generation rate owing to the low cell C-rates. In both instances, a basic radial air cooling approach is still sufficient to limit $\Delta T_{\max }$ to below $1.5^{\circ} \mathrm{C}$.

Figure 11 EV transient thermal model results for 18650 type cell subject to radial air cooling boundary condition (a) $T_{\max }$ evolution (b) $\Delta T_{\max }$ evolution (c) $T_{\text {avg }}$ evolution (see online version for colours)

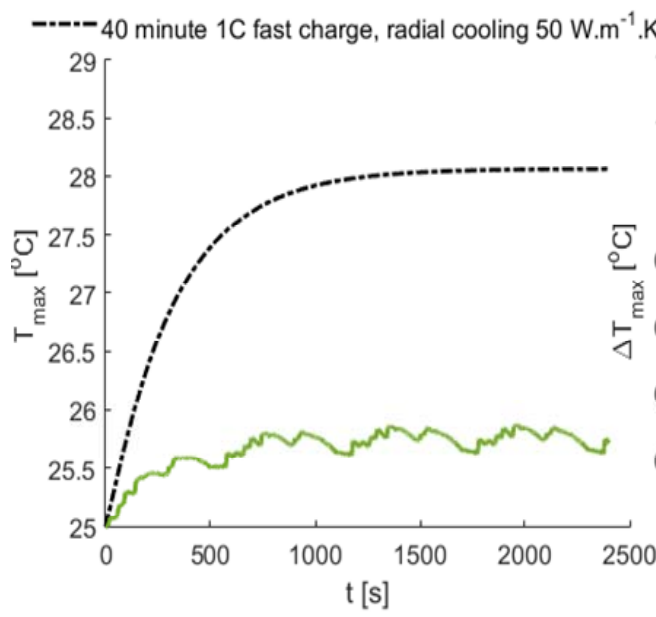

(a)

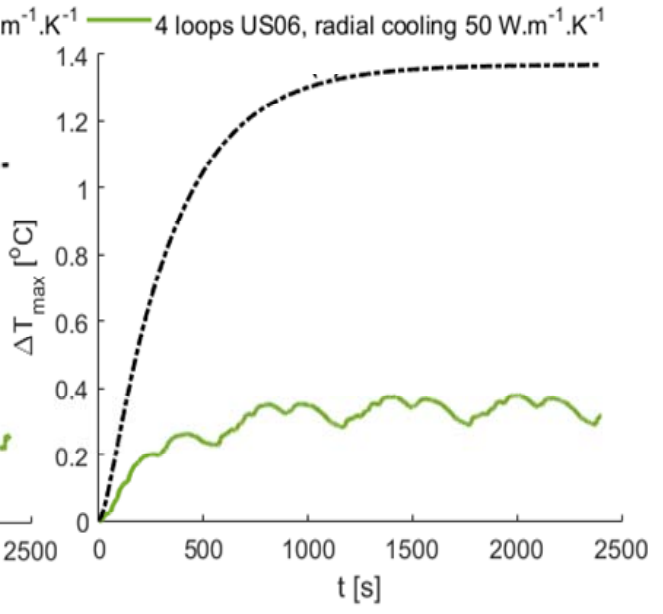

(b)

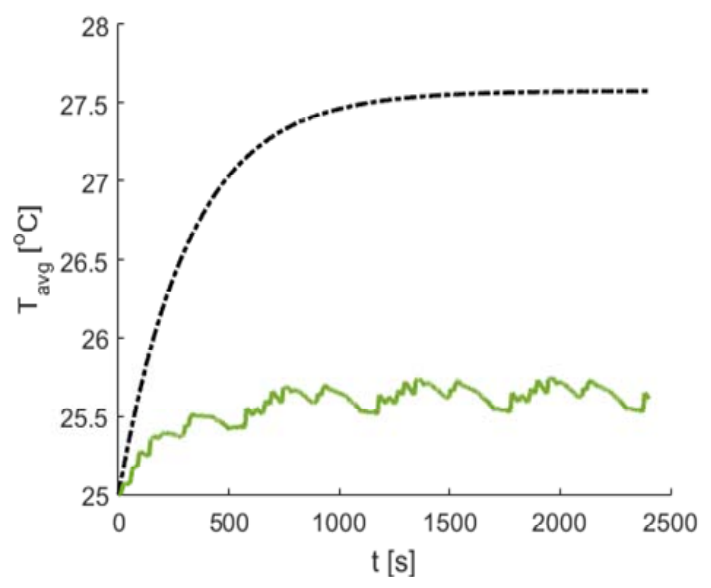

(c) 


\subsubsection{Transient PHEV thermal analysis}

Transient thermal results for the PHEV electrical loading conditions can be viewed in Figure 12 for the Artemis rural road cycle and Figure 13 for the WLTP Class 3 cycle. Each drive cycle is looped back to back three times to provide full quasi steady state temperature profiles. Moderate forced convection of air with $50 \mathrm{~W} \cdot \mathrm{m}^{-2} \cdot \mathrm{K}^{-1}$, as with the steady state analysis, again provides almost identical temperature performance as singular tab cooling with liquid at $750 \mathrm{~W} \cdot \mathrm{m}^{-2} \cdot \mathrm{K}^{-1}$. This implies that the thermal resistance component for heat transport through the 18650 cell material in the axial direction is similar to that in the radial direction.

Figure 12 PHEV thermal model results for 18650 type cell for three loops of Artemis rural road cycle (a) $T_{\max }$ evolution (b) $\Delta T_{\max }$ evolution (c) $T_{\text {avg }}$ evolution (see online version for colours)

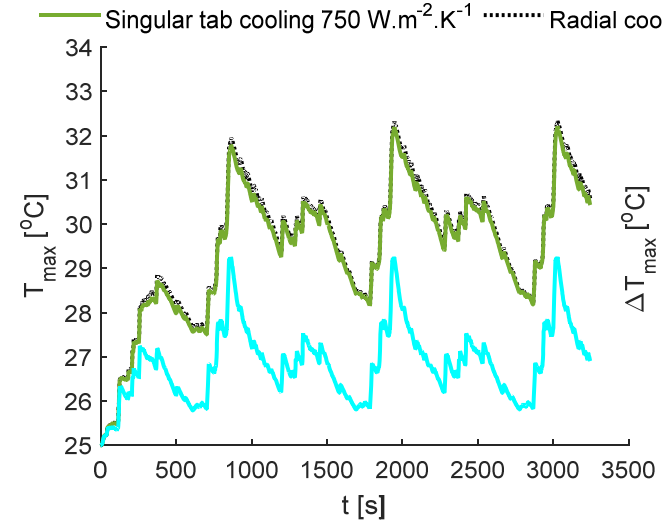

(a)

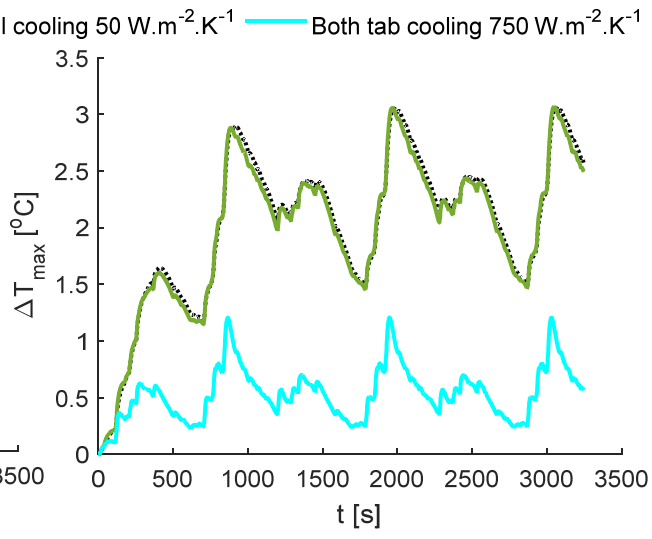

(b)

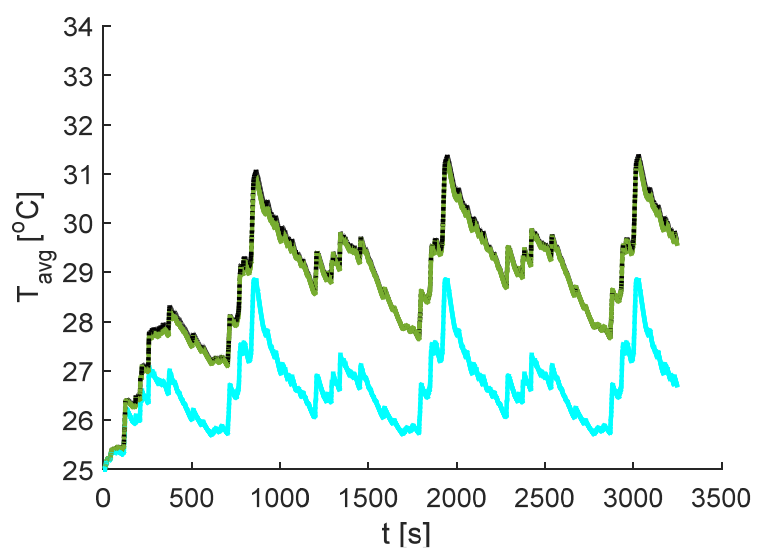

(c)

Figure 12 and Figure 13 highlight that the peaks in $\Delta T_{\max }$ during the transient cycle are higher than that predicted by the steady state analysis using the time averaged heat generation value. This is a result of the higher C-rates experienced during the cycle when compared to that in the EV case as seen in Figure 6. However, $\Delta T_{\max }$ does not exceed 
$5^{\circ} \mathrm{C}$ for all cooling options considered. Radial air cooling may therefore be the most appropriate choice for large sized PHEV applications on the cell level given the reductions in complexity and cost with using air relative to a liquid design (Wang et al., 2016).

Double tab cooling is the only option that offers a significant reduction in cell temperature gradient, together with effectively limiting the amplitude of peak temperature transients.

Figure 13 PHEV thermal model results for 18650 type cell for three loops of WLTP class 3 cycle (a) $T_{\max }$ evolution (b) $\Delta T_{\max }$ evolution (c) $T_{\text {avg }}$ evolution (see online version for colours)

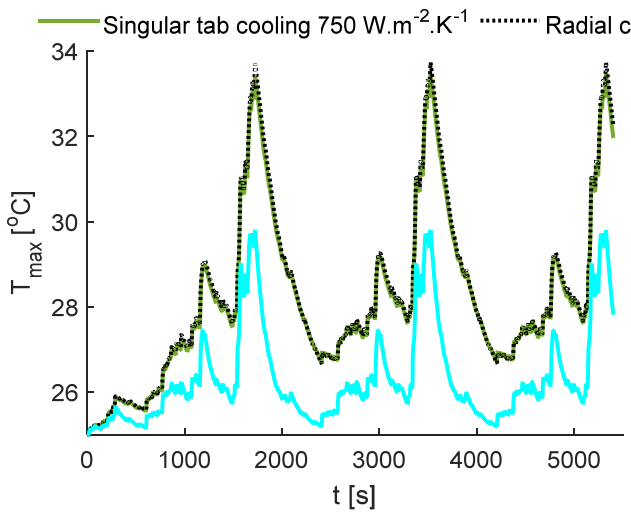

(a)

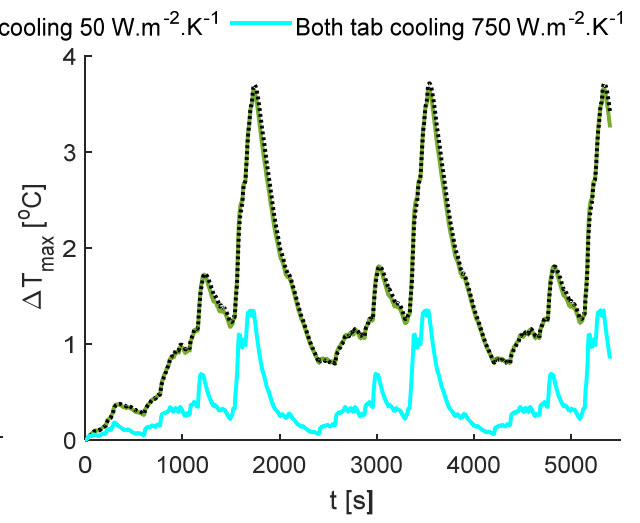

(b)

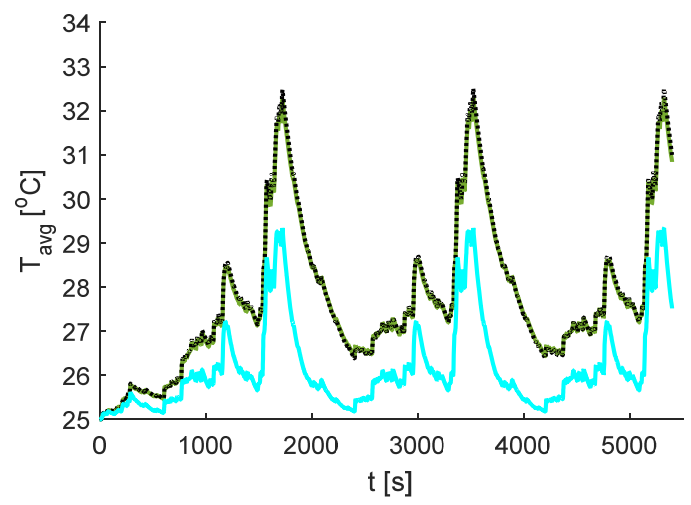

(c)

Transient thermal results for the HEV case subject to four loops of the US06 cycle are shown in Figure 14. Radial cooling with air and singular tab cooling with liquid both lead to severe thermal conditions for the cell, with $\Delta T_{\max }$ and $T_{\max }$ exceeding $15^{\circ} \mathrm{C}$ and $50^{\circ} \mathrm{C}$ respectively during the 4th loop of the US06 HEV cycle. Combining a liquid radial cooling mechanism together with singular tab cooling offers a large reduction in both the value of $T_{\max }$ and $T_{\text {avg }}$ by more than $10^{\circ} \mathrm{C}$ at $t=1970 \mathrm{~s}$. However, this strategy still fails to limit the peak value of $\Delta T_{\max }$ to below $15^{\circ} \mathrm{C}$ which remains highly transient. The greatest dampening effect on the value of $\Delta T_{\max }$ is again observed with liquid double tab cooling, 
enabling the peak value to remain below $5^{\circ} \mathrm{C}$. Relative to the steady state analysis, the transient analysis results in similar peak temperature of within $4^{\circ} \mathrm{C}$ for all cooling strategies when compared to the HEV limit in Figure 9.

Figure 14 HEV thermal model results for 32113 type cell for four loops of the US06 cycle (a) $T_{\max }$ evolution (b) $\Delta T_{\max }$ evolution (c) $T_{\text {avg }}$ evolution (see online version for colours)

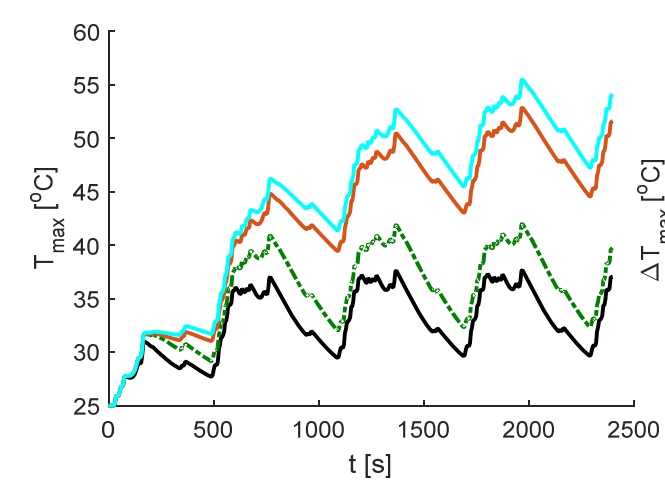

(a)

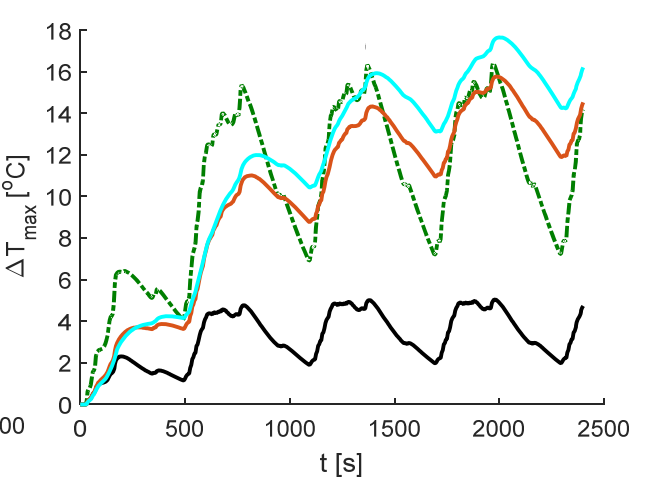

(b)
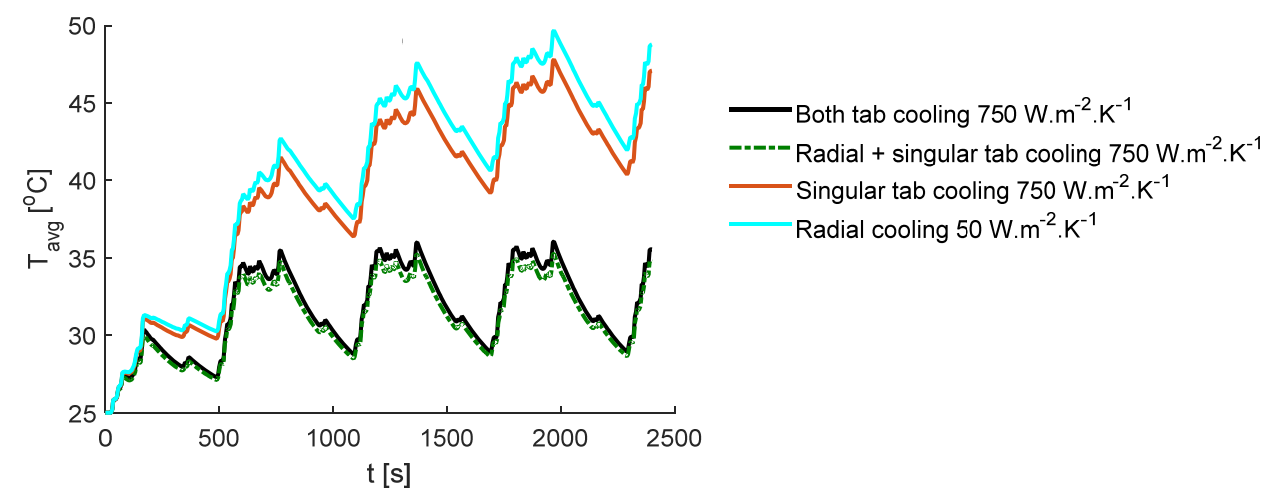

(c)

\section{Cell thermal conductivity sensitivity analysis}

The case study thermal analysis uses effective values for the cell anisotropic thermal conductivity obtained from (Shah et al., 2016; Drake et al., 2014) that includes the effects of thermal contact resistance between cell layers. Given that these values are not measured for either the 18650 type or 32113 type cells considered in this particular thermal analysis, a sensitivity study is performed to investigate the effect of thermal conductivity on cell thermal performance for radial and tab cooling.

Vertiz et al. (2014) report a low end value of $0.175 \mathrm{~W} \cdot \mathrm{m}^{-1} \cdot \mathrm{K}^{-1}$ for the perpendicular thermal conductivity in a 'dry' pouch cell. Without electrolyte, the thermal contact resistance present between layers is higher since the gap thermal conductance is lowered from the presence low conductivity air/gases within the voids formed from contact of the 
material asperities. For a cell saturated with electrolyte, the measured thermal conductivity from Vertiz et al. (2014) increased to $0.284 \mathrm{~W} \cdot \mathrm{m}^{-1} \cdot \mathrm{K}^{-1}$, further highlighting the importance of the electrolyte in increasing the thermal conductivity. Drake et al. (2014) report a lower value (experimental) of $0.15 \mathrm{~W} \cdot \mathrm{m}^{-1} \cdot \mathrm{K}^{-1}$ for a 26,650 cylindrical cell and is one of the lowest values reported in literature. This value is therefore chosen to represent a potential lower bound for the perpendicular thermal conductivity in the sensitivity study. Values as high as $0.4 \mathrm{~W} \cdot \mathrm{m}^{-1} \cdot \mathrm{K}^{-1}$ have been reported by Fleckenstein et al. (2011) for the effective perpendicular thermal conductivity of the cell spiral roll material in a 32113 cell, but this neglects the presence of the outer casing and electrolyte contact layer. A value of $0.50 \mathrm{~W} \cdot \mathrm{m}^{-1} \cdot \mathrm{K}^{-1}$ is chosen as the upper bound in the sensitivity analysis to see the effect of such a high perpendicular thermal conductivity for the cell.

Figure 15 Perpendicular thermal conductivity sensitivity study for the 32113 cell subject to HEV current profile with radial cooling $\left(50 \mathrm{~W} \cdot \mathrm{m}^{-2} \cdot \mathrm{K}^{-1}\right.$ ) (see online version for colours)

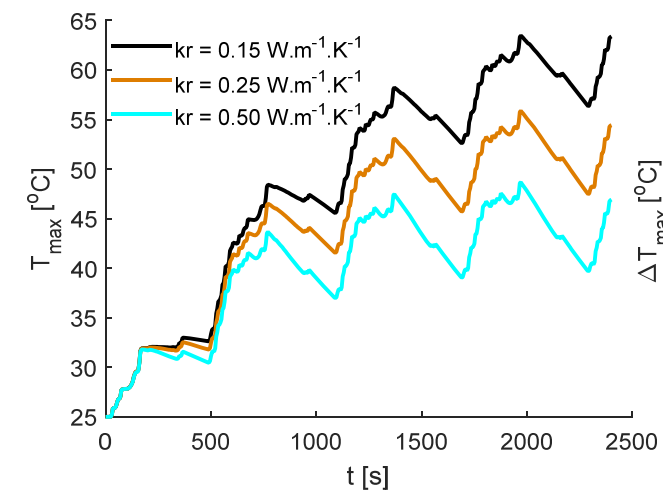

(a)

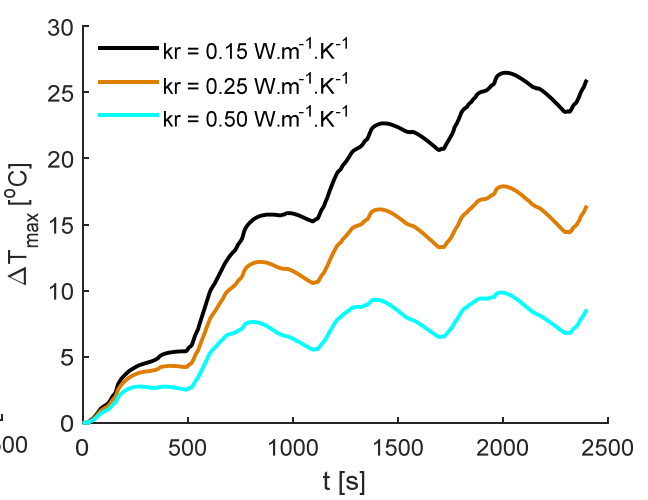

(b)

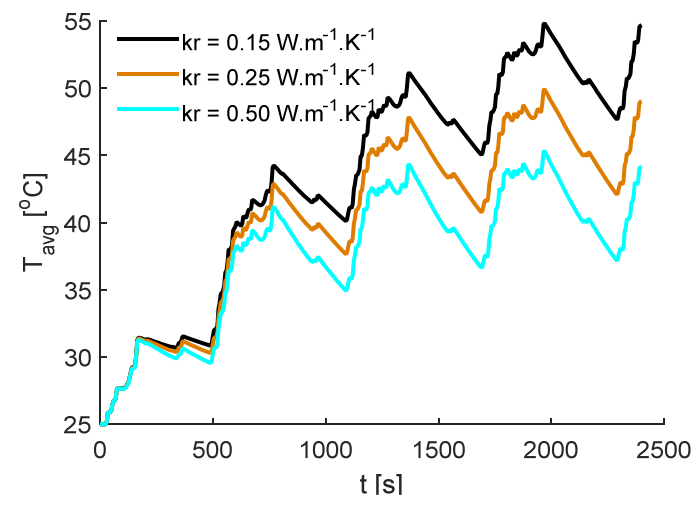

(c)

The results for the perpendicular thermal conductivity sensitivity study can be viewed in Figure 15, which is conducted for the HEV case study with radial only cooling at $50 \mathrm{~W} \cdot \mathrm{m}^{-2} \cdot \mathrm{K}^{-1}$. As seen, increasing the perpendicular thermal conductivity results in a marked reduction in $\Delta T_{\max }$ together with an overall decrease in $T_{\text {avg. }}$. This is attributed to the lower thermal resistance through the cell material as the cell thermal conductivity is 
increased. Specifically, increasing the thermal conductivity from $0.15 \mathrm{~W} \cdot \mathrm{m}^{-1} \cdot \mathrm{K}^{-1}$ by $66.7 \%$ to $0.25 \mathrm{~W} . \mathrm{m}^{-1} \cdot \mathrm{K}^{-1}$ results in the peak temperature gradient decreasing from $26.49^{\circ} \mathrm{C}$ to $17.89^{\circ} \mathrm{C}(32.5 \%$ decrease). Given these results, effort should thus be made to ensure that the cell internals are sufficiently saturated with fluid electrolyte to maximise the perpendicular thermal conductivity if a radial cooling strategy is sought for. However, given that $\Delta T_{\max }$ still approaches circa $10^{\circ} \mathrm{C}$ during the 4th cycle of the US06, with $T_{\max }$ approaching $49^{\circ} \mathrm{C}$, the choice of radial cooling with the upper limit for perpendicular thermal conductivity remains vastly inferior to double tab cooling.

Table 4 Physical properties of common battery materials

\begin{tabular}{lcc}
\hline Material & Thermal conductivity $\left(\mathrm{W} \mathrm{m}^{-1} \cdot \mathrm{K}^{-1}\right)$ & Thickness $(\mu \mathrm{m})$ \\
\hline Graphite electrode & 1.04 & 140 \\
$\mathrm{LiCoO}_{2}$ electrode & 1.58 & 116 \\
$\mathrm{Al}$ foil & 238.0 & 20 \\
$\mathrm{Cu}$ foil & 398.0 & 14 \\
Separator & 0.3344 & 35 \\
Liquid electrolyte (contact layer) & 0.60 & 500 \\
S.S. AISI-304 (metallic housing) & 14.6 & 700 \\
\hline
\end{tabular}

Source: Chen et al. (2005)

For the axial thermal conductivity sensitivity analysis, a deviation of $10 \mathrm{~W} \cdot \mathrm{m}^{-1} \cdot \mathrm{K}^{-1}$ around the value of $30 \mathrm{~W} \cdot \mathrm{m}^{-1} \cdot \mathrm{K}^{-1}$ reported by Drake et al. is specified. This range is considered based on the reported values for the axial thermal conductivity (28.9 W. $\mathrm{m}^{-1} \cdot \mathrm{K}^{-1}-35.1 \mathrm{~W} \cdot \mathrm{m}^{-1} \cdot \mathrm{K}^{-1}$ ) for lithium-ion cells by Bazinski et al. (2016).

The effects of substituting the conventional graphite anodes of lithium-ion cells to axially orientated carbon nanotubes (CNT) with an axial thermal conductivity of $300 \mathrm{~W} \cdot \mathrm{m}^{-1} \cdot \mathrm{K}^{-1}$ as mentioned in Sievers et al. (2010) is also investigated. Chen et al. (2005) report the general thermal conductivity properties and thickness of the individual material layers used in lithium-ion batteries, which are summarised in Table 4. The theoretical calculation for the effective axial thermal conductivity of the battery cell is given by Ye et al. (2014) and Chen et al. (2005):

$$
k_{z}=\frac{\sum_{i} L_{i} k_{z, i}}{\sum_{i} L_{i}}
$$

where $k_{z, i}$ is the axial thermal conductivity of material layer ' $\mathrm{i}$ ' $\left[\mathrm{W} \cdot \mathrm{m}^{-1} \cdot \mathrm{K}^{-1}\right]$ and $L_{i}$ the thickness of battery material layer ' $\mathrm{i}$ ' $[\mathrm{m}]$.

Using this value in replace of $1.04 \mathrm{~W} \cdot \mathrm{m}^{-1} \cdot \mathrm{K}^{-1}$ for conventional graphite anodes in Table 4 together with equation (3), the theoretical effective cell axial thermal conductivity with CNT is calculated as $162 \mathrm{~W} \cdot \mathrm{m}^{-1} \cdot \mathrm{K}^{-1}$.

Figure 16 displays the effect of cell axial thermal conductivity on the thermal performance of the HEV cell subject to bottom tab cooling $\left(750 \mathrm{~W} \cdot \mathrm{m}^{-2} \cdot \mathrm{K}^{-1}\right)$. From $20 \mathrm{~W} \cdot \mathrm{m}^{-1} \cdot \mathrm{K}^{-1}$ to $30 \mathrm{~W} \cdot \mathrm{m}^{-1} \cdot \mathrm{K}^{-1}$ the peak cell temperature gradient along the course of the transient analysis is reduced from $21.81^{\circ} \mathrm{C}$ to $15.81^{\circ} \mathrm{C}(27.5 \%$ decrease). Further increasing the thermal conductivity from $30 \mathrm{~W} \cdot \mathrm{m}^{-1} \cdot \mathrm{K}^{-1}$ to $40 \mathrm{~W} \cdot \mathrm{m}^{-1} \cdot \mathrm{K}^{-1}$ offers a lower 
percentage reduction in $\Delta T_{\max }$ of $21.8 \%$. With the CNT and singular tab cooling, the maximum temperature gradient through the cell is $3.4^{\circ} \mathrm{C}$, less than for the case of double tab cooling. Therefore, provided that issues with CNT for use as anodes in lithium ioncells can be overcome (Kang et al., 2015), it has the potential to be a particularly attractive thermal management strategy when coupled with tab cooling.

Figure 16 Axial thermal conductivity sensitivity study for 32113 cell subject to HEV current profile with bottom tab cooling $\left(750 \mathrm{~W} \cdot \mathrm{m}^{-2} \cdot \mathrm{K}^{-1}\right)$ (see online version for colours)

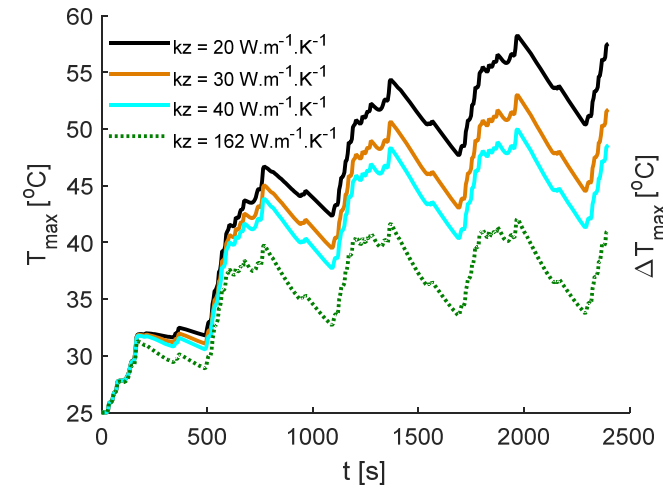

(a)

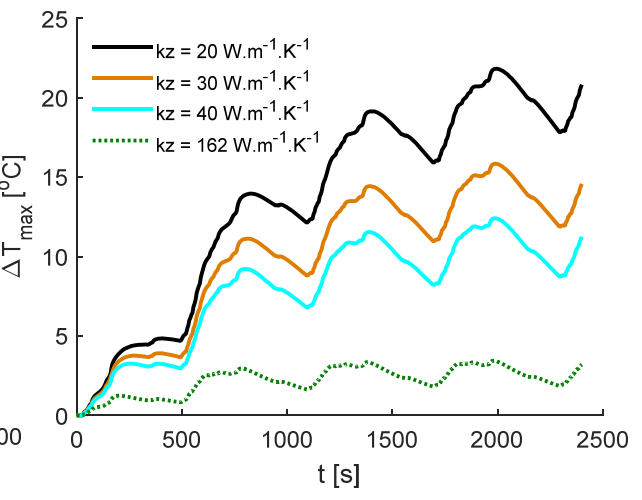

(b)

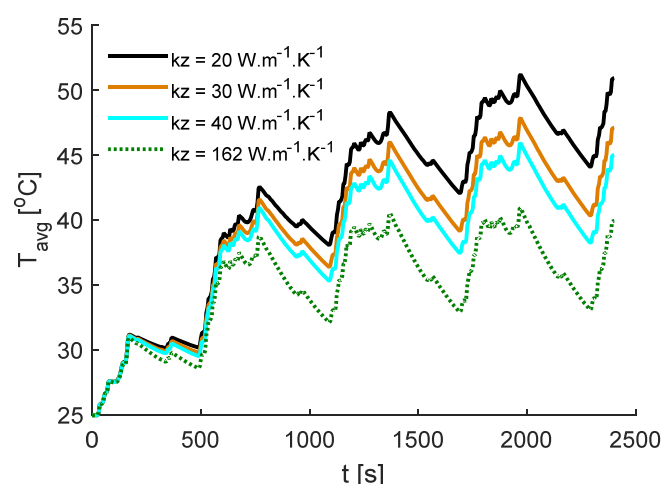

(c)

\section{Recommendation for further work}

Given the limitations of conventional cooling strategies (radial and tab cooling) in thermally managing the cell under high heat generation conditions, additional thermal study should seek to incorporate heat transfer mechanisms that can directly enhance the heat transport through the internal of the cell. Such mechanisms may avoid the need for double tab cooling which can overcomplicate the design of the pack-level thermal management strategy given that cooling must be applied at both ends of the cell. 
Further, additional experiments should be conducted to determine both the effective axial and perpendicular components of the cell thermal conductivity to add to the literature pool of values that includes the presence of contact resistances between layers. These resistances must be captured to avoid underestimating the magnitude of the formed cell temperature gradients and hot spot.

\section{Conclusions}

Results from the steady state thermal analysis indicate that radial cooling 18650 type energy cells with either air or liquid is effective in limiting the cell temperature gradient to below $5^{\circ} \mathrm{C}$ when subject to constant heat generation rates of up to $1.1 \mathrm{~W}$. This value covers the range of time average heat generation values considered for the aggressive EV and PHEV duty cycles, whereby the limiting value for a realistic aggressive application was identified as $0.53 \mathrm{~W}$ for the Artemis rural road PHEV cycle.

Singular tab cooling with liquid results in a similar thermal performance as radial cooling with air, with the difference that the cell hot spot is moved from the core of the cell towards the opposite tab that is not cooled. Combining air cooling at the tabs in addition to at the radial surface offers little benefit within the steady state limit of PHEV time averaged heat generation and therefore does not justify the additional complexity involved with targeting cooling at multiple cell surfaces. For battery packs designed with a liquid heat transfer medium, singular tab cooling is expected to be the preferred choice provided that the convective heat transfer rate is with the region of $750 \mathrm{~W} \cdot \mathrm{m}^{-2} \cdot \mathrm{K}^{-1}$, given the more preferable direction of the thermal gradient that is expected to reduce the overall cell ageing rate.

For 32113 type power cells, radial and singular tab cooling can limit the maximum cell temperature gradient to below $5^{\circ} \mathrm{C}$ up to a steady heat generation of $1.8 \mathrm{~W}$ and $2.1 \mathrm{~W}$ respectively. This is far below the limit for the time averaged value of $6.3 \mathrm{~W}$ across four loops of the US06 HEV cycle. In order to avoid excessive cell degradation rates under these conditions, double tab cooling with a liquid heat transfer medium is required.

Comparison between the steady state thermal results using the time averaged cycle heat generation rates and full transient thermal model did not identify any appreciable differences that would alter the choice of cooling strategy, provided the transient model reaches a quasi-steady state (e.g., by looping the drive cycle of interest multiple times). The difference between the two models becomes larger during cycles with greater fluctuations in the C-rate (e.g., for the $\mathrm{HEV}$ and $\mathrm{PHEV}$ cases) where transient temperature spikes are larger. However, the steady state model is within $4^{\circ} \mathrm{C}$ of the highest peak transient temperature predicted for all cooling cases and analysed electrical loading conditions. The steady sate thermal charts contained within this paper, therefore, provide useful initial design guidelines for facilitating the cylindrical cell-level thermal management choice for a given characteristic time averaged drive cycle heat generation rate. 


\section{Acknowledgements}

The research presented within this paper is supported by the Engineering and Physical Science Research Council (EPSRC-EP/I01585X/1) through the Engineering Doctoral Centre in High Value, Low Environmental Impact Manufacturing. The research was undertaken in collaboration with the WMG Centre High Value Manufacturing Catapult (funded by Innovate UK) in collaboration with Thermacore Europe. Details of additional underlying data in support of this article and how interested researchers may be able to access it can be found here: http://wrap.warwick.ac.uk/91753.

\section{References}

A123 Systems (2011) Nanophosphate High Power Lithium Ion Cell ANR32113M1Ultra-B, MD100113-01 data sheet.

Anderman, M. (2014) The Tesla Battery Report Outline [online] http://doc.xueqiu.com/ 1493d8803372d3fd67cb5c51.pdf (accessed 4 April 2017).

Bandhauer, T.M., Garimella, S. and Fuller, T.F. (2011) 'A critical review of thermal issues in lithium-ion batteries', Journal of the Electrochemical Society, Vol. 158, No. 3, pp.R1-R25.

Barlow, T. et al. (2009) A Reference Book of Driving Cycles for Use in the Measurement of Road Vehicle Emissions, p.280 [online] https://trl.co.uk/reports/PPR354 (accessed 3 March 2017).

Bazinski, S.J. et al. (2016) 'Measuring and assessing the effective in-plane thermal conductivity of lithium iron phosphate pouch cells', Energy, Vol. 114, pp.1085-1092 [online] http://dx.doi.org/10.1016/j.energy.2016.08.087.

Bergman, T. et al. (2011) Fundamentals of Heat and Mass Transfer, John Wiley and Sons, Chicago.

Brand, M.J. et al. (2015) 'Effects of vibrations and shocks on lithium-ion cells', Journal of Power Sources, Vol. 288, No. 1, pp.62-69.

Chen, S.C., Wan, C.C. and Wang, Y.Y. (2005) 'Thermal analysis of lithium-ion batteries', Journal of Power Sources, May, Vol. 140, No. 1, pp.111-124.

Dinger, A. et al. (2010) Focus Batteries for Electric Cars, p.18 [online] http://www.bcg.com/ documents/file36615.pdf (accessed 5 May 2017).

Drake, S.J. et al. (2014) 'Measurement of anisotropic thermophysical properties of cylindrical Li-ion cells', Journal of Power Sources, Vol. 252, pp.298-304 [online] http://dx.doi.org/ 10.1016/j.jpowsour.2013.11.107.

Fleckenstein, M. et al. (2011) 'Current density and state of charge inhomogeneities in Li-ion battery cells with $\mathrm{LiFePO} 4$ as cathode material due to temperature gradients', Journal of Power Sources, Vol. 196, No. 10, pp.4769-4778 [online] http://linkinghub.elsevier.com/ retrieve/pii/S0378775311001558 (accessed 8 March 2017).

Fleckenstein, M. et al. (2013) 'Thermal impedance spectroscopy - a method for the thermal characterization of high power battery cells', Journal of Power Sources, Vol. 223, pp.259-267 [online] http://dx.doi.org/10.1016/j.jpowsour.2012.07.144.

Greco, A. et al. (2014) 'A theoretical and computational study of lithium-ion battery thermal management for electric vehicles using heat pipes', Journal of Power Sources, Vol. 257, pp.344-355 [online] http://dx.doi.org/10.1016/j.jpowsour.2014.02.004. 
Hunt, I.A. et al. (2016) 'Surface cooling causes accelerated degradation compared to tab cooling for Lithium-ion pouch cells', Journal of The Electrochemical Society, Vol. 163, No. 9, pp.A1846-A1852 [online] http://jes.ecsdl.org/lookup/doi/10.1149/2.0361609jes (accessed 1 November 2017).

International Energy Agency (IEA) (2011) Technology Roadmap: Electric and Plug-in Hybrid Electric Vehicles, International Energy Agency, Tech. Rep, June), p.52 [online] https://www.iea.org/publications/freepublications/publication/EV PHEV Roadmap.pdf (accessed 1 November 2017).

Johnson, V.H., Pesaran, A. and Court, B. (2000) 'Temperature-dependent battery models for high-power lithium-ion batteries', Power, pp.1-15 [online] https://www.nrel.gov/docs/ fy01osti/28716.pdf (accessed 1 November 2017).

Kang, C. et al. (2015) 'Three-dimensional carbon nanotubes for high capacity lithium-ion batteries', Journal of Power Sources, Vol. 299, No. 1, pp.465-471 [online] http://linkinghub.elsevier.com/retrieve/pii/S0378775315302585 (accessed 1 November 2017).

Kim, G.H. and Pesaran, A. (2006) 'Battery thermal management system design modeling', 22nd International Battery Hybrid and Fuel Cell Electric Vehicle Conference and Exhibition EVS22, pp.126-133, 1 November [online] http://zanran_storage.s3.amazonaws.com/ www.nrel.gov/ContentPages/184201983.pdf (accessed 1 November 2017).

Maleki, H. (1999) 'Thermal properties of Lithium-Ion battery and components', Journal of The Electrochemical Society, Vol. 146, No. 3, p.947.

Nykvist, B. and Nilsson, M. (2015) 'Rapidly falling costs of battery packs for electric vehicles', Nature Clim. Change, Vol. 5, No. 4, pp.329-332 [online] http://dx.doi.org/10.1038/ nclimate2564 (accessed 1 November 2017).

Onda, K. et al. (2006) 'Thermal behavior of small lithium-ion battery during rapid charge and discharge cycles', Journal of Power Sources, Vol. 158, No. 1, pp.535-542 [online] http://linkinghub.elsevier.com/retrieve/pii/S0378775305013054 (accessed 1 November 2017).

Ozisik, M.N. (1994) Finite Difference Methods in Heat Transfer, 1st ed., CRC Press, Florida.

Park, S. and Jung, D. (2013) 'Battery cell arrangement and heat transfer fluid effects on the parasitic power consumption and the cell temperature distribution in a hybrid electric vehicle', Journal of Power Sources, Vol. 227, pp.191-198 [online] http://dx.doi.org/10.1016/ j.jpowsour.2012.11.039 (accessed 1 November 2017).

Peterson, S.B., Apt, J. and Whitacre, J.F. (2010) 'Lithium-ion battery cell degradation resulting from realistic vehicle and vehicle-to-grid utilization', Journal of Power Sources, Vol. 195, No. 8, pp.2385-2392.

Rabenstein, F. et al. (20110 The Full-Hybrid Powertrain of the New BMW ActiveHybrid 5, pp.1-17 [online] http://www.aachen-colloquium.com/pdf/vortr_nachger/2011/b5.2_griebel_ bmw.pdf (accessed 1 November 2017).

Rao, Z. et al. (2013) 'Experimental investigation on thermal management of electric vehicle battery with heat pipe', Energy Conversion and Management, Vol. 65, pp.92-97 [online] http://dx.doi.org/10.1016/j.enconman.2012.08.014.

Schneider, R. (2003) Explicit and Implicit Finite Difference Methods for the Diffusion Equation in Two Dimensions, FZKA [online] https://books.google.co.uk/books?id=LOnoQgAACAAJ (accessed 1 November 2017).

Schweiger, H-G. et al. (2010) 'Comparison of several methods for determining the internal resistance of lithium ion cells', Sensors, Vol. 10, No. 6, pp.5604-5625 [online] http://www.mdpi.com/1424-8220/10/6/5604/ (accessed 1 November 2017).

Shah, K. et al. (2016) 'Experimental and numerical investigation of core cooling of Li-ion cells using heat pipes', Energy, Vol. 113, pp.852-860 [online] http://dx.doi.org/10.1016/ j.energy.2016.07.076. 
Shah, K., Drake, S.J. et al. (2014a) 'An experimentally validated transient thermal model for cylindrical Li-ion cells', Journal of Power Sources, Vol. 271, No. 1, pp.262-268 [online] http://www.sciencedirect.com/science/article/pii/S0378775314011720 (accessed 1 November 2017).

Shah, K., Drake, S.J. et al. (2014b) 'Modeling of steady-state convective cooling of cylindrical Li-ion cells', Journal of Power Sources, Vol. 258, pp.374-381 [online] http://dx.doi.org/ 10.1016/j.jpowsour.2014.01.115.

Sievers, M., Sievers, U. and Mao, S.S. (2010) 'Thermal modelling of new Li-ion cell design modifications', Forschung im Ingenieurwesen, Vol. 74, No. 4, pp.215-231 [online] http://link.springer.com/10.1007/s10010-010-0127-y (accessed 1 November 2017).

Tourani, A., White, P. and Ivey, P. (2014) 'Analysis of electric and thermal behaviour of lithium-ion cells in realistic driving cycles', Journal of Power Sources, Vol. 268, pp.301-314 [online] http://dx.doi.org/10.1016/j.jpowsour.2014.06.010 (accessed 1 November 2017).

Troxler, Y. et al. (2014) 'The effect of thermal gradients on the performance of lithium-ion batteries', Journal of Power Sources, Vol. 247, pp.1018-1025 [online] http://linkinghub.elsevier.com/retrieve/pii/S0378775313010914 (accessed 1 November 2017).

Tutuianu, M. et al. (2014) Development of a World-wide Worldwide Harmonized Light Duty Driving Test Cycle, Technical Report 03, pp.7-10, January.

Vertiz, G. et al. (2014) 'Thermal characterization of large size lithium-ion pouch cell based on 1d electro-thermal model', Journal of Power Sources, Vol. 272, pp.476-484 [online] http://dx.doi.org/10.1016/j.jpowsour.2014.08.092 (accessed 1 November 2017).

Viswanathan, V.V. et al. (2010) 'Effect of entropy change of lithium intercalation in cathodes and anodes on Li-ion battery thermal management', Journal of Power Sources, Vol. 195, No. 11, pp.3720-3729 [online] http://dx.doi.org/10.1016/j.jpowsour.2009.11.103.

Wang, Q. et al. (2016) 'A critical review of thermal management models and solutions of lithium-ion batteries for the development of pure electric vehicles', Renewable and Sustainable Energy Reviews, Vol. 64, No. 1, pp.106-128.

Yang, N. et al. (2016) 'Unbalanced discharging and aging due to temperature differences among the cells in a lithium-ion battery pack with parallel combination', Journal of Power Sources, Vol. 306, pp.733-741 [online] http://linkinghub.elsevier.com/retrieve/pii/ S0378775315306911 (accessed 1 November 2017).

Ye, Y. et al. (2014) 'Effect of thermal contact resistances on fast charging of large format lithium ion batteries', Electrochimica Acta, Vol. 134, pp.327-337 [online] http://dx.doi.org/ 10.1016/j.electacta.2014.04.134.

Yoo, H.D. et al. (2014) 'On the challenge of developing advanced technologies for electrochemical energy storage and conversion', Materials Today, Vol. 17, No. 3, pp.110-121 [online] http://dx.doi.org/10.1016/j.mattod.2014.02.014.

Zhao, J., Rao, Z. and Li, Y. (2015) 'Thermal performance of mini-channel liquid cooled cylinder based battery thermal management for cylindrical lithium-ion power battery', Energy Conversion and Management, Vol. 103, pp.157-165 [online] http://dx.doi.org/10.1016/ j.enconman.2015.06.056. 


\section{Nomenclature}

\begin{tabular}{|c|c|c|}
\hline Symbol & Meaning & Unit \\
\hline$z$ & Axial position & {$[\mathrm{m}]$} \\
\hline$L$ & Cell length & {$[\mathrm{m}]$} \\
\hline$r$ & Radial position & {$[\mathrm{m}]$} \\
\hline$R_{i}$ & Mandrel radius & {$[\mathrm{m}]$} \\
\hline$R_{o}$ & Cell radius & {$[\mathrm{m}]$} \\
\hline$h_{z l}$ & Convective heat transfer coefficient across top tab & {$\left[\mathrm{W} \cdot \mathrm{m}^{-2} \cdot \mathrm{K}^{-1}\right]$} \\
\hline$h_{z 0}$ & Convective heat transfer coefficient across bottom tab & {$\left[\mathrm{W} \cdot \mathrm{m}^{-2} \cdot \mathrm{K}^{-1}\right]$} \\
\hline$h_{r}$ & Convective heat transfer coefficient across outer radial surface & {$\left[\mathrm{W} \cdot \mathrm{m}^{-2} \cdot \mathrm{K}^{-1}\right]$} \\
\hline$\rho$ & Material density & {$\left[\mathrm{kg} \cdot \mathrm{m}^{-3}\right]$} \\
\hline$C_{p}$ & Material heat capacity & {$\left[\mathrm{J}^{\mathrm{kg}}{ }^{-1} \cdot \mathrm{K}^{-1}\right]$} \\
\hline$q^{\prime \prime \prime}$ & Cell volumetric heat generation & {$\left[\mathrm{W} . \mathrm{m}^{-3}\right]$} \\
\hline$t$ & Time & {$[\mathrm{s}]$} \\
\hline$k_{r}$ & Perpendicular thermal conductivity & {$\left[\mathrm{W} \cdot \mathrm{m}^{-1} \cdot \mathrm{K}^{-1}\right]$} \\
\hline$k_{z}$ & Axial thermal conductivity & {$\left[\mathrm{W} \cdot \mathrm{m}^{-1} \cdot \mathrm{K}^{-1}\right]$} \\
\hline$T$ & Temperature & {$[\mathrm{K}]$} \\
\hline$S O C$ & Cell state of charge & {$[\%]$} \\
\hline$l$ & Cell current & {$[\mathrm{A}]$} \\
\hline$R_{\eta}$ & Overpotential/internal resistance of cell & {$[\Omega]$} \\
\hline$v_{c}$ & Volume of the cell bulk material & . \\
\hline$T_{\max }$ & Maximum temperature of bulk cell material & {$[\mathrm{K}]$} \\
\hline$\Delta T_{\max }$ & Maximum temperature gradient through bulk cell material & {$[\mathrm{K}]$} \\
\hline$T_{\text {avg }}$ & Volume averaged temperature of bulk cell material & {$[\mathrm{K}]$} \\
\hline$P p$ & Propulsion power $(\mathrm{Pp})$ & {$[\mathrm{W}]$} \\
\hline$C_{d}$ & Vehicle drag coefficient & {$[-]$} \\
\hline$L_{i}$ & Thickness of battery material layer ' $i$ ' & {$[\mathrm{m}]$} \\
\hline$k_{z, i}$ & Axial thermal conductivity of material layer ' $\mathrm{i}$ ' & {$[\mathrm{m}]$} \\
\hline$V_{\text {cell }}$ & Cell voltage & {$[\mathrm{V}]$} \\
\hline$N_{\text {cell }}$ & Number of cells in battery pack & {$[-]$} \\
\hline$C_{\text {cell }}$ & Nominal cell capacity & {$[\mathrm{Ah}]$} \\
\hline$E_{\text {pack }}$ & Nominal pack energy & {$[\mathrm{kWh}]$} \\
\hline
\end{tabular}

